International Journal of Social Science and Economic Research

ISSN: 2455-8834

Volume:06, Issue:07 "July 2021"

\title{
IMPACT OF COVID-19 ON EUROPEAN TOURISM INDUSTRY
}

\author{
SAMARTH GUPTA \\ Sarla Anil Modi School of Economics, NMIMS Mumbai \\ DOI: 10.46609/IJSSER.2021.v06i07.018 URL: https://doi.org/10.46609/IJSSER.2021.v06i07.018
}

\begin{abstract}
Outbreak of Novel Coronavirus across the globe has transpired into an industry emergency for Tourism and sectors linked to it. This research study investigates the impact of the virus on 4 major European travel destinations i.e UK, Spain, France and Italy with respect to their pre and post COVID data pertinent to industry performance indicators and associated sectors i.e. Insurance and Aviation. In furtherance of Consumer/ Traveler's perception, this paper reveals the behavioural pattern of 108 individuals to scrutinize the factors affecting their travel choices such as destination, period of travel and risk aversion.
\end{abstract}

Key Words : COVID-19, tourism, travel, policies and measures , fiscal and monetary response , aviation industry

\section{INTRODUCTION}

Originating in the city of Wuhan, China, in December 2019, the virus SARS-CoV-2, popularly known as COVID-19 has now spread to 216 countries globally. Countries around the world are struggling to control the transmission of infection, with many countries even experiencing a second wave of this communicable disease. Consequently, the SARS-CoV-2, was declared a pandemic, by the World Health Organisation in March 2020. The World Health organization defines an epidemic as "The occurrence in a community or region of cases of an illness, specific health-related behaviour, or other health-related events clearly in excess of normal expectancy. The community or region and the period in which the cases occur are specified precisely." [1] As pandemics are epidemics which are spread over a wide area, an analysis of the two naturally goes hand in hand.

Despite significant medical progress over the last centuries, these epidemics and diseases pose a significant threat to society. The most important and crucial aspect of an epidemic is the loss of human life. Moreover, the spread of the virus has great repercussions on the national or regional economies. Europe, which ranked 1st as the most- visited continent in the world at $58 \%$ in the Global Travel Statistics (2016) report, has been a popular tourist destination for tourists all over 
the world. In Fact in 2018, European tourism contributed 10.1\% to the European GDP. The first case of COVID-19 in Europe was recorded on 21st January, 2020. Since the inception of the disease, about 45 million people have been a victim of the SARS-CoV-2 in Europe, with more than 0.9 million deaths recorded in the continent, according to European Centre for Disease Prevention and Control. COVID-19 has proven to be not only a health crisis but also an economic crisis. The International Monetary fund estimated the European GDP to contract by 7\%, highest since The World War 2.

\section{Table: COVID-19 Cases Situation by WHO Region}

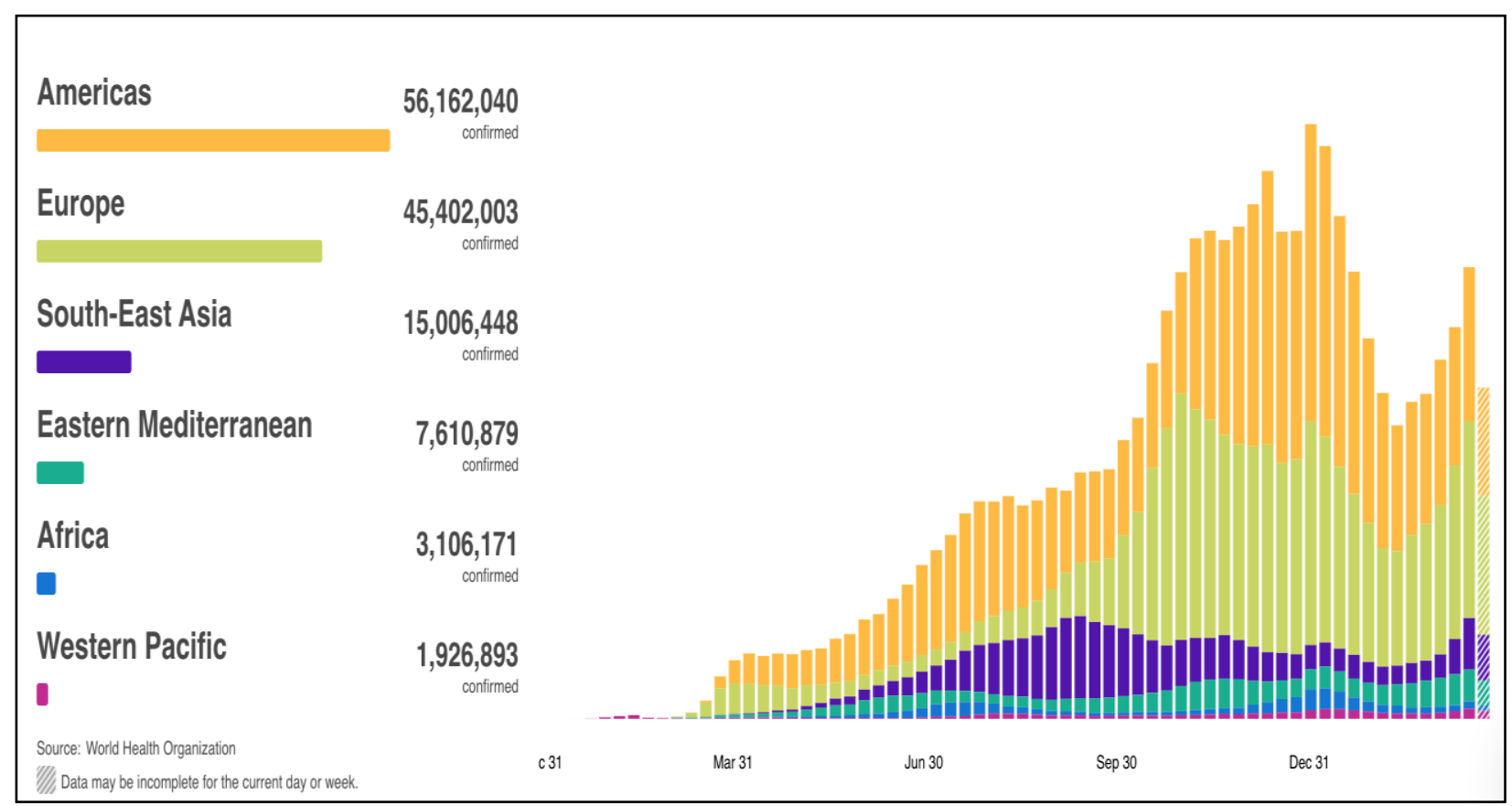

Source: World Health Organization (2021)

Furthermore, COVID-19 has impacted each and every sector of the global economy, resulting in depressed demand and sluggish prospects of growth. This paper focuses on the Tourism sector which in 2019 accounted for more than 10\% of the global GDP. According to the World Travel and Tourism Council, the Travel and Tourism Sector has led to the creation of 330 million jobs worldwide, with one out of every 10th person working in this sector. There is an inverse relationship between pandemic outbreaks and international tourism. According to Gössling, Scott, and Hall (2020), the COVID-19 pandemic will have serious consequences on international tourism, and will in turn will have a chain effect on the prosperity and economic growth of various countries. Additionally, Yang et al. (2020) illustrated the impact of epidemic 


\section{International Journal of Social Science and Economic Research}

ISSN: $2455-8834$

Volume:06, Issue:07 "July 2021"

outbreaks which are infectious in nature, with an emphasis on COVID-19 and indicated a serious concern for the tourism industry whose very existence depends on human mobility.

This study will examine the impact of COVID-19 on the tourism sector of Europe by comparing pre-covid and prevailing figures, focusing on four European nations, namely: France, Spain, Italy and the United Kingdom. France ranks as the number 1 tourist destination worldwide by United Nations World Tourism Rankings in 2019, due to its iconic landmarks, architecture, great history and fashion. Italy is famous for its authentic cuisine and culture, ranks 3rd in international tourist arrivals (2019) in Europe. Thirdly, this city is famous for its vast coastline, football and scenic beauty, aka Spain, which attracts millions of tourists every year. Lastly, the study dives into the tourism sector of the United Kingdom, one of the most influential financial hubs globally, with London, the city of dreams residing in its heart.

The first half of the paper explores previously published studies and literature pertinent to Epidemics and Tourism . Secondly, we move on to ascertain the impact of Novel Coronavirus on the world's most popular travel continent with a detailed analysis providing regional comparison for aforementioned destinations. The research also discerns the implications of global travel restriction and policy responses on respective economies by providing a critical analysis of interlinkages between them. Lastly, we analyse the changing consumer and traveler's perception with regard to the dynamic nature of global tourism. This study will differ from current researches in terms of data range, analysis methods and data sets. In conclusion we will discuss the recommendations and policy implications for the Tourism Industry in the post COVID era and scope for future studies.

\section{REVIEW OF LITERATURE}

Review of Literature has been divided into three sections. The first section discusses the evolution of the tourism sector and its rapid integration in the global economy. The next section provides insight into the relationship between epidemics and tourism with a special focus on its economic importance. Other serious epidemics like Ebola, Swine Flu, SARS, MERS and Avian Flu are also discussed in this section. This is followed by the last section which discusses the studies emphasizing upon the inter linkages between COVID-19 and the tourism sector.

The growing importance of tourism as an economic sector has led the industry to become one of the largest sectors in the world GDP, with a contribution of 5\% to the world economy and $7 \%$ of the total employment. As the consumer emphasis on social, recreational and cultural activity has developed immensely over the century consequently the tourism sector also experienced a robust and coherent development. In order to scrutinize the evolution of this sector thoroughly Mihai 


\section{International Journal of Social Science and Economic Research}

ISSN: $2455-8834$

Volume:06, Issue:07 "July 2021"

and Simoni (2010) gather and inspect the progression and structure of the indicators ${ }^{1}$ of tourism flows. The primary bibliographical and data sources were extracted from the Department of Statistics and Economic Quantification of Tourism of $\mathrm{UNWTO}^{2}$ and the Tourism Satellite Account and subsequently concluded. The physical indicators are represented by the number of tourist arrivals and departures at the border or accommodation units while the value indicators are measured by the effect of tourism consumption ${ }^{3}$ and effort ${ }^{4}$. Average receipts or expenditure per tourist daily is determined by integrating physical and value indicators.

Furthermore the authors emphasize on the tremendous increase in the international tourist flow from 561 million tourists in 1996 to 980 million tourists in 2011. Stagnation was observed in 2000-2003 and due to the economic crisis in the tourism sector, there was a decrease in international tourists in 2009. However, 2010-2011 was a period of immense recovery with a growth rate of $4.4 \%$. The recovery was greater in advanced economies (5\%) than in emerging economies (3.8\%). The WTO has identified the five main tourist regions: Europe, Asia and the Middle Pacific, the Americas, Africa and the Middle East, each including their respective subregions. Europe ranks at the top of the international tourism arrivals with 502 million tourists amounting up to $51 \%$ of international tourist arrivals, followed by Asia and the Pacific attracting 216 million tourists and the Americas with 216 million international tourists. The major tourist arrival destinations were France, the U.S.A, China, Spain, Italy, the U.K, Turkey, Germany, Malaysia and Mexico. The growth in international tourism in Europe was concentrated in Mediterranean Europe and Central and Western Europe with a growth rate of $7 \%$ and $4.5 \%$ respectively. An estimated growth rate of $3-4 \%$ with 1 billion international tourists was forecasted for the year 2012. The international tourism receipts exceeded $\$ 900$ billion annually which is an increase of $4.7 \%$ in the year 2009 International tourism exports exceeded $\$ 1000$ billion in 2010 which is $\$ 3$ billion a day.

Similarly, a very interesting research was conducted by Lew (2011). The study focuses on the international travel exports because of its evident impact on the destination place's economy. Tourism ranks at the fifth or sixth place when estimated by WTO's international trade numbers. It is marginally smaller by agriculture which is preceded by fossil fuels, telecommunications and computer equipment and automotive products. He describes the tourism industry as daunting as

\footnotetext{
${ }^{1}$ Physical and Value Indicators

${ }^{2}$ United Nations World Tourism Organisation

${ }^{3}$ Measured by sales volume for domestic tourism

${ }^{4}$ Total domestic tourism consumption expenditure
} 


\section{International Journal of Social Science and Economic Research}

ISSN: $2455-8834$

Volume:06, Issue:07 "July 2021"

it is challenging to measure the actual size of the global tourism economy. Nevertheless, to measure some part of it, data can be extracted from the World Trade Organization (WTO). The WTO is not the same as the United Nations World Tourism Organisation (UNWTO) since it only takes into account travel receipts. The estimated world total tourism receipts by the World Travel and Tourism Council (WTTC) is twice than that of the WTO. This indicates that domestic tourism receipts are roughly equal to the international receipts. The WTTC's data is based on Tourism Satellite Accounting (SAT) ${ }^{5}$, making it unreliable for comparison. Hence, we could infer that the domestic tourism economy and international tourism economy are fairly similar.

In addition to this, Lew (2011) states that since international travel flourishes in Europe, its domestic travel is smaller whereas in China domestic travel exceeds international by the ratio of 20:1. Tourism is the largest Service Sector Economy since the preceding five industries fall under Merchandise Product Industries in terms of international trade. Under WTO's Commercial Services, travel and tourism has been separated into transportation ${ }^{6}$ and travel $^{7}$. The difference between the tourism exports and tourism imports is known as tourism balance of trade or tourism balance of payments. Globally, the total export receipts is equivalent to the total import expenditure although it differs for every country. Approximately two-thirds of EU members are in the tourism balance of payments surplus. A significant economic surplus is when receipts exceed expenditures by a factor of two or more ${ }^{8}$. The Tourism Sector from the WTO's data includes Travel Services, passenger Transportation Services (excluding freight), and the recreation portion of the Other Commercial Services sector. Conjointly the tourism sector accounts for $6.4 \%$ of the international trade exports and one-third of the total commercial services. Transportation services makes up for $22.9 \%$ in international commercial services exports and travel services account for $27.1 \%$. International tourist receipts expanded by $9 \%$ in 2006 ensuring stable growth. However, the tourism industry has been slowly declining since 2000 .

In conclusion, with the rise in tourism destinations, investments in tourism have also shot up leading to prospective employment, infrastructural development and socioeconomic

\footnotetext{
${ }^{5}$ This modus operandi is unique for every country.

${ }^{6}$ Transportation services undertaken by one economy's residents for another economy. It consists of the carriage of passengers, the movement of goods (freight), rentals (charters) of carriers with crew, and related supporting and auxiliary services

${ }^{7}$ Goods and services of an economy obtained travellers for a visit of one year or lesser to that economy.

${ }^{8}$ Greece (4.5×), Spain (3.2x), Malta (2.8x), Portugal (2.6x) and Cyprus (2.5×)
} 


\section{International Journal of Social Science and Economic Research}

ISSN: $2455-8834$

Volume:06, Issue:07 "July 2021"

development. Moreover, as per the WTO estimates tourism sector a third of commercial services and would stand at the position of 6th largest sector in the global economy.

Epidemics deter economic growth by changing expectations about how well an economy will function hampering tourism and investment moreover prolonged epidemics have both short term and long term ramifications. Bloom and Canning (2006) examined the significant economic impacts of epidemics on countries using secondary sources of research. They discuss how the health scare caused during SARS reduced the Foreign direct investment by $62 \%$ in one quarter in Hong Kong. They also found that each additional year of life expectancy increases per capita GDP by $4 \%$. Moreover, in situations of high unemployment, there may be no change in the total output, since those who die are replaced by new workers. However, in the case of skilled workers dying, there would be negative financial repercussions and fall in output. One of the factors to measure the cost of the epidemic is the value of human life, indicating their costliness. During an epidemic, the people who die, as well their family, lose out economically. Moreover, loss of intangible assets like love felt by friends and relatives of the dead and lost companionship further add to losses. Moreover, the global survey (AIDS) 20had business leaders convey their concerns over the current and future impact of the pandemic on the company operations and workforce. $16 \%$ of respondents indicated that the virus had a serious impact on their business. This figure increased to 35\% in low-income countries and 45\% in Sub-Saharan Africa. The study concludes that how globalisation can on one hand expedite the reach of new diseases, and on the other provide an opportunity to tackle the epidemic.

According to the World Bank \$2.2 billion was lost in Gross Domestic Product of the three countries Guinea, Liberia, and Sierra Leone due to Ebola. The Centers for Disease Control and Prevention in (2019) stated that there were 28,639 suspected, probable, and confirmed cases of Ebola and around 11,316 deaths during the 2014 Ebola epidemic in West Africa. The outbreak resulted in substantial loss in private sector growth, agricultural production leading to concerns about food security and cross-border trade as restrictions on movement, goods, and services increased. The impact on the health care sector was: a total of 881 confirmed health worker infections and 513 deaths were reported in Guinea, Liberia, and Sierra Leone. ${ }^{9}$ Moreover, Liberia lost $8 \%$ of its doctors, nurses, and midwives to Ebola. Furthermore, Sierra Leone and Guinea lost $7 \%$ and $1 \%$ of their healthcare workers, respectively. Moreover, the treatment and control of other diseases, HIV, Tuberculosis and Malaria. Since healthcare services were reduced by $50 \%$ in the three most affected countries, an estimated additional 10, 600 lives were lost to HIV, tuberculosis and malaria during the epidemic. Children were greatly affected by the Ebola outbreak. Nearly $20 \%$ of all Ebola cases occurred in children under 15 years old. In June 2014,

\footnotetext{
${ }^{9}$ The affected countries
} 


\section{International Journal of Social Science and Economic Research}

ISSN: $2455-8834$

Volume:06, Issue:07 "July 2021"

all schools in Guinea, Liberia, and Sierra Leone closed because of the epidemic. By the time the schools reopened in 2015, students had lost approximately 1,848 hours of education due to school closure. Ranging from around 33 weeks in Guinea to 39 weeks in Sierra Leone. To prevent disease transmission to other countries more than 339,000 people were screened at airports before leaving Guinea, Liberia and Sierra Leone.

The outbreak of Ebola had a serious negative impact on Africa particularly on tourism, The flights were ceased and travel warnings were being issued to the areas affected by Ebola. The outbreak of the virus was geographically concentrated in Central and Western Africa, specifically the Democratic Republic of Congo (DRC). Maphanga and Henam (2019) reviewed secondary data for research. From December 2013 to 17 November 2014, the World Health Organisation (WHO) reported 14,415 confirmed and suspected cases with 5.177 reported deaths of the Ebola virus disease (EVD) in six affected countries ${ }^{10}$ and two previously affected countries $^{11}$. The EVD has been generalized to the whole of Africa as a continent, even in countries where there was no trace of the virus affecting tourism greatly. Sierra Leone, a country in West Africa was a tourist attraction which led to an increase in visitor expenditure, employment generation and generation of revenue was greatly affected by the EVD. This consequently led to shutting down of hotels, restaurants, airlines and guesthouses causing a decline in revenue and large scale unemployment in the country. Morocco suspended the African Cup of Nations (AFCON) tournament which was scheduled in January 2015. Flights from Sierra Leone were suspended and travelers were heavily screened at the airports. The main tourist attractions of the country were not visited even by the residents which was followed by a state of emergency. Libera, one of the poorest countries in Africa experienced tremendous rates of infection making the country $\$ 100$ million poorer than it would have been if it wasn't affected by the virus. There was a 50-75\% decline in turnover for commercial and tourism industries. Nigeria experienced a reduction in tourism and travel restrictions with a 20-40\% decline in overall demand in Lagos. There was a drop of $1 \%$ in the annual GDP drop of Senegal due to the outbreak of the EVD. WHO and the Governments of Guinea, Sierra Leone and Liberia sought urgent financial support of approximately US\$ 71,053,413 to implement the outbreak plan.

It is noted that for certain countries, favourable climatic conditions for tourism is linked with favourable conditions for infectious diseases, indicating tourism's contribution to the economy is huge and has high potential.Rossello, Santana-Gallego and Awan (2017) evaluated the economic

\footnotetext{
${ }^{10}$ Guinea, Liberia, Mali, Sierra Leone, Spain and the United States of America

${ }^{11}$ Nigeria and Senegal
} 


\section{International Journal of Social Science and Economic Research}

ISSN: $2455-8834$

Volume:06, Issue:07 "July 2021"

implications of eradicating epidemics: Malaria, Dengue, Yellow Fever and Ebola on the countries that were affected, focusing on the expenditure from tourism. For estimation, a gravity model for international tourism flows is used which estimates the impact of each travel-related disease (TRD) on its international tourist arrival. Additionally, the potential eradication of these diseases in the countries which are affected is stimulated and its impact on the expenditure from tourism is computed. The dependent variable is You which is the no. of tourist arrivals (international) from country of origin $\mathrm{i}$ to destination country $\mathrm{j}$ during year $\mathrm{t}$. For the period 2000-2013, 208 origin countries and 196 destination countries are taken into account. While several explanatory variables including per capita real gross domestic product of the destination country, population of the country of destination and distance in kilometres between country of origin and destination country are used. The results demonstrate that Yellow Fever and Malaria are the diseases that played the most vital role in determining a tourists destination choice. Moreover, the risk of travel related diseases results in a decrease of 37\% in inbound tourism figures. Furthermore, the eradication of Malaria, Dengue, Yellow Fever and Ebola in the affected countries would increase around 10 million tourists worldwide and also increase the tourism expenditure by US $\$ 12$ billion. In the case of malaria there would be an increase of $6.2 \mathrm{mn}$ tourists and US\$3532 million in the countries affected i.e. $19.8 \%$ growth in the tourist arrivals.

The swine flu or H1N1 reassorted subtype causing the first global pandemic in the last 40 years resulted in substantial and prolonged illness, hospitalizing million people and numerous deaths across the globe. During the global financial crisis in 2008 as the credit crunch was intensifying with simultaneous aggravation of swine flu or H1N1 outbreak had a significantly negative influence on the global economy. Page, Song and $\mathrm{Wu}$ (2011) provided a synopsis on the impacts of two significant phenomena causing a prominent impact on UK Tourism using Time Varying Parameter Model to establish the linkage between demand for tourism and explanatory variables i.e. tourism price ${ }^{12}$, visitor income and substitute tourism price ${ }^{13}$. The data has been divided into two periods i.e. 1993 Q1-2007 Q4 for estimation and 2008Q1-2009Q2 for ex post forecasting. To characterise the effect on the sector the author examined tourism from principal source markets i.e. 14 countries accounting for $60.6 \%$ of the total arrivals in the UK. The findings revealed that swine flu led to an estimated loss of 1.6 million potential visitors in the second quarter of 2009. Global policy responses such as advisory against travel, quarantine measures for suspected cases and thermal screening were primary causes that caught global media

\footnotetext{
12 tourist prices and tourism incomes are measured using economic indicators, including Exchange rates , CPI and GDP.

${ }^{13}$ France was used as a substitute destination because of factors such as similar tourist products and geographical proximity.
} 


\section{International Journal of Social Science and Economic Research}

ISSN: $2455-8834$

Volume:06, Issue:07 "July 2021"

attention leading to a severe contraction in the tourism demand. The sudden slump in arrivals from Spain , South Korea, China and Russia resulted in substantial direct revenue losses. Where the two events combined led to a loss of $£ 4.7$ billion out of which $£ 940$ million to the swine flu outbreak i.e. about $20 \%$ of total revenue (direct). Out of all 14 source markets, Spain and the United States were the highest contributors to swine flu related losses i.e. $1164.3 \mathrm{mn}$ and $£ 114$ mn respectively whilst Japan and Hong Kong had the least impact on UK revenue reductions.

In order to disentangle the effects of Swine Flu (SF) from the effects of the earlier Global Financial Crisis (GFC) on the tourism industry Haque and Haque ( 2016) conducted a study on Brunei Tourism Industry by implementing two auto regressive integrated moving average (ARIMA) models for SF and GFC respectively and one intervention time series analysis (ITSA) method. Monthly foreign tourist arrivals data was taken from Brunei Tourism Development Department from January 2005 - May 2010. It was observed 126,000 tourists ${ }^{14}$ arrived in 2005 which subsequently increased to 226,000 in 2008 just before the GFC and declined to 157,000 tourists after both the GFC and SF had occurred. The survey sample size was 600, 200 pre-SF and 400 post-SF.. A significant decline was noted in the tourist numbers in April 2008 which could be due to the American financial crisis that spread throughout the world. Usually, May is considered as a peak tourist arrival month but there was a decline in the number of tourists in May-June 2009 by $42.8 \%$. This is likely due to the combined effect of SF and GFC. A decline of $7.1 \%$ was also observed in May-June 2009 which could be due to SF. Therefore, two intervention points June 2009 and September 2008 have been noted for SF and GFC respectively. After successfully using the methodology developed, it was observed that Brunei lost 123,737 tourists due to GFC and 29,919 tourists due to SF in the 12 month post-SF period. A survey also indicated that the average expenditure per tourist was $\mathrm{B} \$ 150$ and they stayed for an estimate of 3.4 days which sums up to a total of $B \$ 510$ spent by a tourist during their course of stay in Brunei. When the figure is multiplied by the number of tourists lost, Brunei lost approximately $\mathrm{B} \$ 14,882,820$ due to $\mathrm{SF}$ in the post SF period. In order to recover the economy, the Brunei Tourism Development Department engaged in promotional activities by the end of 2009 which resulted in a 20\% increase in tourists and hotel bookings for the first 6 months of 2010 but was still subsequently lower than the predicted numbers. The swine flu pandemic had a significantly negative influence on UK Tourism. Where tourists from the United States and Germany recorded maximum decline in arrivals, Asian markets demonstrated the least impact.

The spread of the avian influenza virus H5N1 had extensively damaged the world economy and led to amplification of risks as a result of spread of infection to its new host i.e humans . Chang,

${ }^{14}$ Foreign tourists consisted of overnight transit, government exhibition, business, holidays, visiting friends and relatives 


\section{International Journal of Social Science and Economic Research}

ISSN: $2455-8834$

Volume:06, Issue:07 "July 2021"

Chen and Huang (2009) provided an insight on the impact of Avian flu on Asian and global tourism industry corresponding to 12 severely infected countries ${ }^{15}$. To assess the average impact on the tourism sector the author uses static and dynamic models where international tourism demand is approximated by using number of international tourist arrivals, volume of earnings generated by foreign visitors and the number of nights spent by visitors from abroad as proxies. As tourism data is widely concerned with seasonality the model accounts for the same by deseasonalizing the data through multiplicative moving average method in order to avert spurious and biased results. The results for the Static model state that for every poultry outbreak tourism demand significantly declined by about 67 arrivals and 74 arrivals for global countries and asian countries respectively. Similarly for the dynamic model the figures stood at 147 arrivals and 167 arrivals respectively. Consequently it was ascertained that avian flu lead to a greater damage to Asian economies primarily because prolonged spread of the epidemic and lack of effective prevention leading to an adverse image of the affected destinations.Furthermore some other elements such as travel advisories and restrictions pertaining to avian flu , mass consumption of chicken as food source and lack of public health considerations could be potential reasons for detrimental effects on the global tourism industry.

SARS-CoV or coronavirus caused the first-century pandemic which originated Guangdong Province of China during November 2002 and rapidly disseminated to 30 countries within 8 months. Consequently 10 years later, MERS-CoV, a second coronavirus, originated in the Middle East eventually infecting more than 2000 individuals across the globe. Joo , Maskery, Berro , Rotz , Lee and Brown (2019) reviewed the impact of the 2015 MERS outbreak on the Republic of Korea(ROK) with respect to 3 travel related service sectors- accommodation, food and beverage, and transportation. The economic impact was calculated using the seasonal autoregressive integrated moving average models (SARIMA) for monthly numbers of noncitizen arrivals during and after the MERS outbreak (June 2015- June 2016). The month of May 2015 was not a part of the study because the outbreak lasted only for a third of that month and the travelers would not have enough time to review their travel. The outbreak lasted from May 2015 to December 2015 after which the WHO declared it ended in the ROK. The data for the research was obtained from TOURGO for the number of noncitizen arrivals in ROK which was generated using the guidelines from UNWTO. The citizens of Korea living abroad were excluded from the study. International tourism receipts per foreign traveler were also extracted from TOURGO. The average expenditure per noncitizen traveler between June and September ranged from \$997 to $\$ 1,296$ per traveler, varying each. Each spending area's proportions from the international

${ }^{15}$ Monthly time series data for China, Cambodia, Indonesia, Japan, Korea, Malaysia, Thailand, Turkey, Vietnam,Romania, Hungary and Egypt. 


\section{International Journal of Social Science and Economic Research}

ISSN: $2455-8834$

Volume:06, Issue:07 "July 2021"

tourism receipts were obtained by the Korea Institute for Industrial Economics and Trade which were subsequently used to determine the impact on the 3 travel-related areas. It ranged from $20.9 \%$ for accommodation, $13.9 \%$ for food and beverage, and $4.1 \%$ for transportation. The monthly tourism changes in revenue was investigated by multiplying the estimated monthly changes in numbers of noncitizen visitors' arrivals by the average international tourism receipts per capita of each month. There was a drastic drop in the number of noncitizen arrivals between June and September 2015. From October to December 2015 the noncitizen arrivals recovered to expected numbers without the MERS outbreak. However, 6 months after the outbreak (JanuaryJune 2016) there was no significant difference between the actual values ${ }^{16}$ and the projected values $^{17}$. There was a significant decline in the accommodation ${ }^{18}$ and food and beverage ${ }^{19}$ service sectors between June-July 2015 while the transportation ${ }^{20}$ index was only significantly low in June 2015. However, there was no visible impact on the GDP growth of ROK in 2015 since there was a 5\% growth with respect to 2014. This is due to the fact that the tourism industry made up only $5.1 \%$ of ROK's total GDP.

The severe impact of SARS and MERS was also discernible on the aviation sector .The International Air Transport Association (IATA) published a bulletin (2020) regarding the impact of past epidemics on air travel. It highlighted that in recent times, SARS has been the most serious epidemic which greatly impacted the traffic volumes of the aviation industry. The monthly RPKs of Asia-Pacific airlines at the peak of the outbreak (2003) were 35\% lower as compared to the pre-crisis levels, however, returned to its pre-crisis level within 9 months of the outbreak. Moreover, in 2003, leisure travel and business were greatly impacted, both domestically and internationally, due to fear of global epidemic spread and loss of confidence among consumers and businesses. This resulted in Asia-Pacific airlines losing US\$6 billion of revenues overall including a loss of $8 \%$ of the annual RPKs or revenue passenger miles. However, this bulletin also brings to light the two episodes of epidemic avian flu in 2005 and 2013, which has had a much gentler and short term impact on the aviation industry and the air travel revived rapidly as the fear of its global spread softened. Furthermore, in the case of MERS

\footnotetext{
place

${ }^{18} 22.6 \%$ lower than expected in June 2015

${ }^{19} 9.9 \%$ lower than expected in June 2015

${ }^{20} 5.3 \%$ lower than expected in June 2015
}

${ }^{16}$ actual number of noncitizen visitors' arrivals in month

${ }^{17}$ the projected number of noncitizen visitors' arrivals in month i.e if the MERS outbreak did not take 


\section{International Journal of Social Science and Economic Research}

ISSN: $2455-8834$

Volume:06, Issue:07 "July 2021"

Flu, which was mostly confined to a single country, the immediate effect (first month of outbreak) was a sudden slowdown which included RPKs declining by $12 \%$, to, from and within South Korea. Nevertheless, air travel volumes began recovering following two months and restored to its pre-outbreak level in 6 months.

Therefore the past epidemics and virus outbreaks i.e. Ebola, Influenza A, Swineflu, SARS and MERS have left notable dent in the growth of the tourism sector for nummersors developed and developing economies across the globe. The damage from these outbreaks is not only contained to tourism but also has had a spillover effect on industries such as Aviation, Hotel and Transportation. The challenge is now to take a lesson from this global tragedy to accelerate the transformation of sustainable tourism.

Coronavirus or COVID-19 outbreak and subsequent precautionary initiatives to restrict its contagious nature are manifesting clear implications on human mobility at global scale. Such consequences are prominent in several regions across the world. Global tourism has been exposed to a wide range of crises in the past. Tourism as a system has been vulnerable to external shocks. However, there is much evidence that the impact and recovery from the COVID-19 pandemic will be unprecedented. Gossling, Scott and Hall (2020) The rapid emergence, scientific understanding, and responses to COVID-19 evolved over approximately eight weeks, and tourism organizations struggled to understand what was actually happening. As a result of travel restrictions and lockdowns, global tourism slowed down majorly, with the number of global flights dropping by more than half: as the number of cases rose, travel bans grounded a growing number of carriers. Countries all over the world have faced a great loss in GDP output and loss in a number of air sector jobs. For anyone employed in global tourism, the current crisis might have become a personal one. With most hotels being closed or experiencing vastly lower tourism numbers, 2020 industry revenue forecasts point to a significant decline. Major sports leagues across Europe, North America and other countries have ended their seasons with the opening of others including the 2020 Summer Olympic Games (postponed). The combined economic impact is not yet known but will be in the hundreds of billions of US dollars. Restaurants will also face problems recovering, since they have limited liquidity and small profit margins. Cruise ships also won't be able to sail again before a vaccine is found or unless passengers can be tested before boarding. The COVID-19 pandemic should lead to a reconsideration of the global growth for tourism, for interrelated risks incurred in global travel and the sector's contribution to climate change. With the magnitude of the COVID-19 pandemic, there is an urgent need to not return to business-as-usual when the crisis is over, rather than take an opportunity to reconsider a transformation of the global tourism system.

Tourism linked activities have witnessed negative effects because of internal processes. The ongoing pandemic without or with state quarantine impositions and measures infuses a 


\section{International Journal of Social Science and Economic Research}

ISSN: $2455-8834$

Volume:06, Issue:07 "July 2021"

noticeable steep decline in "social consumption". These restrictions include domestic tourism , restaurant visits, cultural events and trade fairs (Hoque, Shikha, Hasanat, Arif, \& Hamid, 2020).

Similarly, Farzanegan , Gholipour, Nunkoo and Andargoli ( 2020) examined the inter linkages between COVID-19 outbreak and international tourism for 92 countries. The paper discusses the repercussions of pandemic are not only restricted human loss of life but also comprise of long and short term economic, political and social effects. They hypothesize that higher outbound and inbound international tourists levels transmit to a higher number of void cases and casualties. A cumulative sum for confirmed deaths and cases is used as proxy for dependent variable ${ }^{21}$ and international tourism measured through $\log$ of no. of arrivals and departures of international tourists from 2010 to $2019^{22}$. A strong correlation between confirmed cases \& deaths with international tourism ${ }^{23}$ i.e. 0.78 . Results from multiple regression analysis indicated a noteworthy association between a country's exposure to COVID-19 and flows of international tourism , where, $1 \%$ increase in tourism over a period of 10 years has led to $1.2 \%$ increase in confirmed covid cases. Similarly , $1 \%$ increase in tourism over a period of 10 years has led to $1.4 \%$ increase in confirmed covid casualties. These findings portray strong policy implications for popular tourist economies such as Spain, France and Italy etc. In addition to this, the intensity and growth of pandemic infections can be steeply reduced through imposition of safety and health standards, closing international borders and effective coordination amongst immigration and health authorities.

After looking at the overall impact of COVID-19 on the different sectors, understanding the impact of COVID-19 on every important sector extensively is crucial for deep understanding of that particular sector. The tourism and hospitality industry thrives on the patterns of visitations and a great amount of research focuses on the development of new tourism products to increase inflows and the multiplier effect of the industry. The ongoing pandemic has taken a serious toll on the education sector across the globe, especially tourism and hospitality that increasingly depend on practical sessions. Kaushal and Srivastava (2020) employ a qualitative stance of research where the method of data collection considered was email interviews. 42 individuals were approached for their participation in the study, out of which 15 accepted to participate. These participants were in senior positions and were mostly occupied with various tasks, thus avoiding delays. Most prominent theme was related to the skills of the employees. It was suggested that going forward specialisation of employees may take a backseat and increased

\footnotetext{
${ }^{21}$ Figures obtained from the European Centre for Disease Prevention and Control (ECDC, 2020).

${ }^{22}$ World Bank

${ }^{23}$ Arrivals and departures
} 


\section{International Journal of Social Science and Economic Research}

ISSN: $2455-8834$

Volume:06, Issue:07 "July 2021"

involvement in multiple jobs might become a norm in hospitality and tourism. Hygiene and sanitation remained a consistent theme throughout all the responses, be it about future consumer behaviour or learnings for the industry educators or trainers. The idea of retaining optimism and hopes of revival remained quite high. Participants shared mixed opinions about media response to the ongoing pandemic and crisis management remained a recurring response under various categories of inquiries. Going forward, it would be crucial for the governments and marketing firms to undertake research to analyse the effects of the current catastrophe on the industry. This study is subject to certain limitations. First and foremost, the research is based on the qualitative analysis which may not justifiably work toward generalisation of the results. Another important limitation that should be addressed is that the perspectives reported in the study are from India. However The pronounced effects of tourism are going to remain for a longer duration and sectors that thrive on social contacts such as tourism and hospitality need to embrace for tumultuous times ahead.

Consumer perception towards contagious diseases such as coronavirus is also an effective indicator of sectoral performances across the global economies. (Uğur and Akb1yık , 2020) investigated the impact of COVID-9 pandemic on the tourism sector through a detailed analysis of travellers reaction captured through the platform Tripadvisor ${ }^{24}$. A total of 75000 comments (approx.) and 23515 cases of infections from Europe, Asia and The USA forums were examined through data and text mining for the purpose of the study. Coronavirus, corona, virus and COVID were the keywords for which the dataset was recorded for mining i.e. a total of 1329825 words. Text mining helps to understand the thematic structure and provide clear insights on tourist perception and declarations. It was discovered that $40.81 \%$ cancellation was linked to the surge in cases within a particular region pushing the tourism industry into a bottleneck . High frequency of travel insurance occurrence in the dataset is an indicator of diminishing tourist confidence amidst pandemics. Another strong revelation from the analysis suggests the growing importance for travel insurance and its market given likelihood of crises and risks associated with international travels. Therefore the growing concerns of individuals linked to fragility of tourism sectors calls for immediate action in the industry.

Nevertheless , Covid-19 has emerged as a reset opportunity for numerous developing economies which struggled to infuse growth in their existing tourism structures. Sanjay (2020)evaluates the changing opinion of travellers revolving around international tourist culture post Covid-19. This paper examines the dynamics of the tourism industry in Nepal and other small economies amidst the pandemic. The first half of the paper states the shortcomings of Nepal's adventure tourism

\footnotetext{
${ }^{24}$ Tripadvisor, Inc. is an American online travel company that operates a website and mobile app with
} user-generated content and a comparison shopping website. 


\section{International Journal of Social Science and Economic Research}

ISSN: $2455-8834$

Volume:06, Issue:07 "July 2021"

sector which was thoroughly reliant on the 2020 Visit Nepal Year programme estimating more than 2 million tourists inflows. The unforeseen circumstances that shaped the community dependent sector into a community crisis. This industry was subservient to assumptions of constant inflow of tourists to Nepal given the international travel growth, the same case can be replicated to other countries such as New Zealand, Australia, Slovenia, Norway and Iceland. In Nepal the sector has perpetually been conditional to global tourism trends, since the global financial crisis(2008-09) that witnessed a decline of more than 40 million tourists within a year, the international tourist arrivals have picked up to 1.46 Billion (WTO,2020)in 2019. Attributing the sudden halt of the tourism industry to Covid-1 Pandemic the author reciprocates the ongoing scenario into a reset opportunity for the country. Nepal's adventure tourism transformation into becoming a major partner for contribution of mindful and sustainable travel with reconceptualization of its classic adventure theme with steady infusion of cultural parts and parcels will make it an all inclusive experience. By prioritizing and emphasizing upon quality rather than quantity, any tourist destination on globe can reestablish its sector through sensible development from mass to class tourism. Sanjak K. also puts forward his recommendations that are vital for resurgence of Nepal's tourism sector. Improvisation and reorientation through diversification of tourism markets ${ }^{25}$, restructuring of tourism infrastructure which focus on sanitation, hygiene, easy access to healthcare services ${ }^{26}$, restricting the expansion of tourism to every district of the country, extension of tourism experience serving to all age groups and comprising spiritual experiences. Sanjay (2020) expresses a strong disconnect between the UNWTO's practices and goals, where the resources are targeted to expansion of tourism rather than sustainability.

Over the years Travel and Tourism has consistently contributed to Spain's economy significantly, Tourist GDP generated nearly 147 billion euro during 2018 which stands at $12.3 \%$ of Spanish GDP. In addition to this, the sector has evolved into one of most prominently growing domains of the economy, with nearly $25.3 \%$ growth in income level between 2015 to 2018 and $13 \%$ in the employment levels. In Britain, Travel and Tourism surpasses banking and automotive by contributing $11 \%$ to the national GDP compared to $6.1 \%$ and $3.2 \%$ respectively $^{27}$ . As per ONS i.e. The Office for National Statistics 2016 , UK and France's Tourism sector witnessed an $11.72 \%$ and $10.75 \%$ jump in employment with more than three million and 4.2 million people workers respectively.

\footnotetext{
${ }^{25}$ Nepal's freefall of 2020 tourism can be attributed to its overreliance on China

${ }^{26}$ Nepal's tourism industry is prone to lack of public sanitation facilities and price wars

${ }^{27}$ https://www.travelweekly.co.uk/articles/338682/travel-and-tourism-fastest-growing-sector-in-uk
} 


\section{International Journal of Social Science and Economic Research}

ISSN: $2455-8834$

Volume:06, Issue:07 "July 2021"

Proceeding from popular views and insightful studies correlating the impact of pandemics and outbreaks on Tourism this research addresses and explores the 4 prime European travel destinations i.e UK, France, Italy and Spain through industry data and policy responses for national tourism recovery. This study also emphasizes the unexplored factors affecting travel preferences and consumer behavioural pattern with respect to travel surrounding, destinations , policy choice and risk aversion.

\section{DATA AND METHODOLOGY}

This study emphasizes the impact of COVID-19 outbreak on Tourism industry whilst discerning the spillovers on other sub-sectors as well. In lieu of rapidly changing consumer perception towards this industry this study has been divided into two parts i.e. Chapter 1 : The Collapse of European Tourism and Policy responses and Chapter 2: Changing Travellers Perception.

Chapter 1 of the paper addresses the impact on the world's most popular continent for tourist attractions , Europe. Conducive to the continent's performance we focus our research on top 4 countries $^{28}$ contributing the most to the Travel and Tourism industry in Europe i.e. France, Spain , Italy and the United Kingdom. Indicators such as International Tourist Arrivals , International Receipts , tourism GDP, employment generated by Tourism , Aviation industry , Travel insurance and so on were evaluated using Growth and De- Growth pattern with cross tabulation , scatter plotting and bubble trends, Area and line charts with trend line study to conduct an expansive cross country analysis on Tourism Industry across the 4 nations.

With regard to their performance we use secondary information extracted from literature research, grey literature focusing on official reports, field reports, statements, statements and guidelines for the Travel and Tourism industry. The sources and articles involving grey literature were browsed from relevant organisation websites such as World Health Organisation, World Travel and Tourism Council, OECD Tourism Statistics, IATA, European Center for Disease Control and Prevention and World Tourism Barometer.

Chapter 2 evaluates and discerns the dynamism in consumer perception towards Travel and Tourism post COVID-19 a primary research survey for 108 participants was conducted. These interviews were conducted through digital questionnaires for adults aged between 18-23 years. In order to capture a holistic view of consumer behaviour we employ univariate sample analysis with weighting (Solon, Haider, \& Wooldridge, 2015; Winship \& Radbill, 1994) to obtain insightful descriptive results. For multivariate analysis, the weighting scheme was negated based

\footnotetext{
${ }^{28} \mathrm{https}$ //www.schengenvisainfo.com/travel-guide/top-10-most-visited-european-countries/
} 
International Journal of Social Science and Economic Research

ISSN: 2455-8834

Volume:06, Issue:07 "July 2021"

on the dominant view provided by (Pfeffermann, 1993; Solonet al., 2015; Winship \& Radbill, 1994).

In order to analyse the perception over travel culture post the outbreak, respondents were gilded to choose between "Yes" or "No" to the question "Whether or not their travel plans were affected by COVID-19 outbreak?".Question pertinent to travel destination preference prior to virus outbreak with option of "Domestic" or "International" was put forward to capture the contrast in consumer behaviour followed by a similar question apposite to post virus outbreak preferences. Due to increasing risk aversion of consumers (Outlook India , 2021) towards travelling, hence the role and purchase pattern for Travel Insurance was captured in the questionnaire as well. Whilst the effect and repercussions of virus outbreak still looms over the global economy questions regarding expected period of travel were incorporated to draw policy implications for Tourism Councils, the response was recorded with " within 6 months " " "within 9 months" and " after COVID-19". The unanticipated closure of the industry has resulted in numerous losses of declared and undeclared revenue due to displacement of traditional perceptions therefore we aim to assess the same phenomena.

\section{ANALYSIS AND INTERPRETATION}

\section{1: The Collapse of European Tourism and Policy Responses}

Amidst surge in COVID-19 Europe witnessed 60\% decline in International Tourist Arrivals during March'20. With a dramatic hit taken by the industry the Eurostat figures depicted consistent decline in April, May and June by 97\% , 95\% and 88\% respectively. Albeit the damage caused to the industry has been prominent, researchers have urged the need for evaluation of wider impacts of the outbreak on specific sectors (Williams, 2020).

UNWTO estimates predicted more 713 million international tourists in 2020 for Europe compared to 1.4 billion of global international tourists ${ }^{29}$. In 2019 France, Spain, Italy and the United kIngdom had $86.9 \mathrm{~m}, 81.8 \mathrm{~m}, 58.3 \mathrm{~m}$ and $37.7 \mathrm{~m}$ international visitors respectively. Every 1 in 3 destinations in europe witnessed nearly $70-79 \%$ decline wreaking havoc on the Continent's Tourism.

${ }^{29} \mathrm{https}$ ://www.schengenvisainfo.com/travel-guide/top-10-most-visited-european-countries/ 
International Journal of Social Science and Economic Research

ISSN: $2455-8834$

Volume:06, Issue:07 "July 2021"

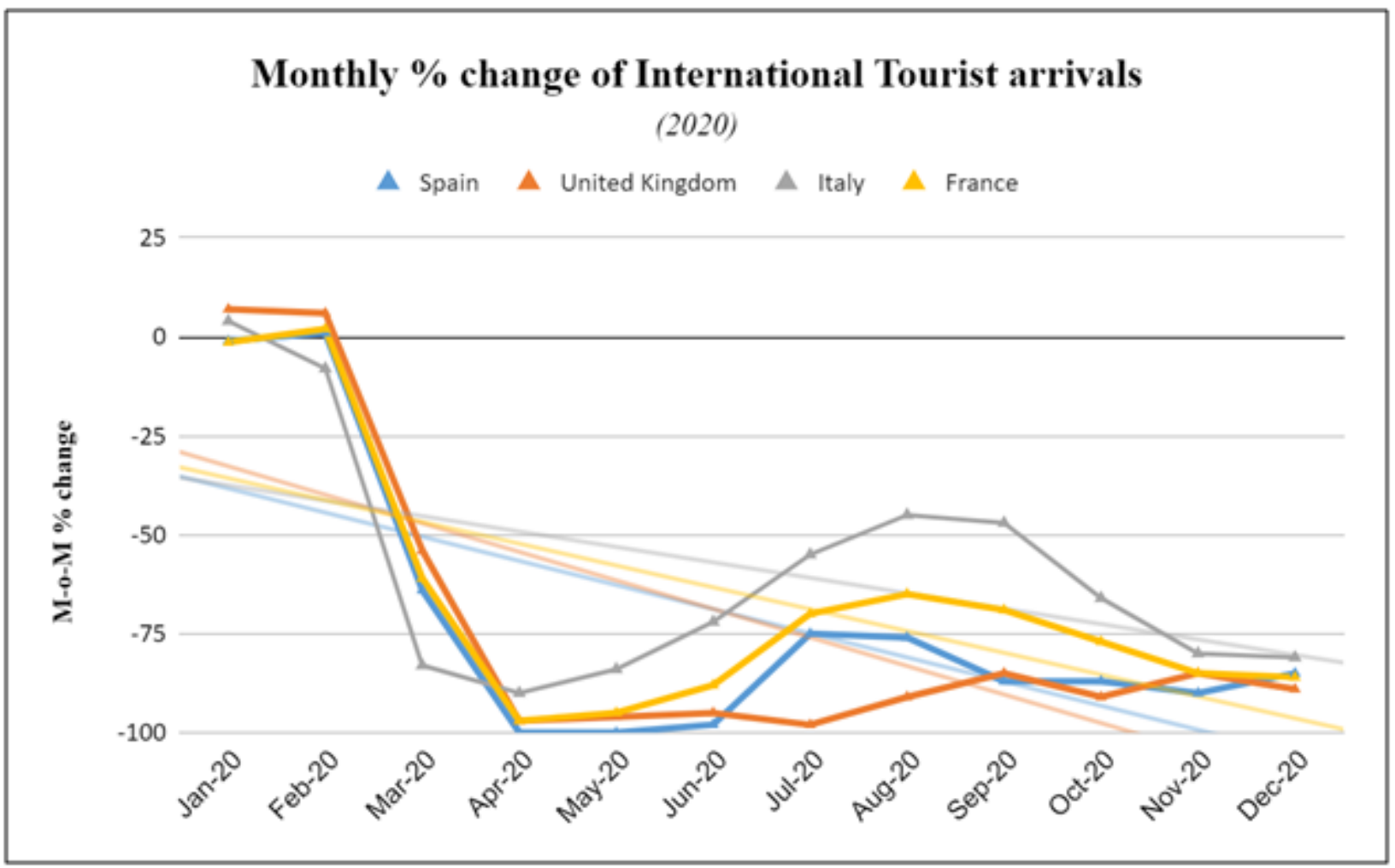

Fig 1.1 Source : Data retrieved from UNWTO barometer

Data findings from UNWTO on M-o-M \% change in International Tourist Arrivals indicated a sharp slump throughout 2020 for all 4 nations, All 4 countries i.e. The UK, Spain, Italy and France witnessed the steepest decline during the months of April and May 2020. With over 500 million fewer tourist arrivals this year, the region also suffered its largest decline in absolute terms. As per the trends indicated in the graph above, The United kingdom exhibited the weakest signs of revival with a persistent downward trend having declined by more than $(-75 \%)$ in M-o-M change from March onwards (Fig 1.1). Italy on the contrary illustrated quick signs of revival from Jun'20 to Oct'20 with the M-o-M change declining to (-50\%). France and Spain also depicted miniscule signs of revival during the same period. Albeit all 4 economies depicted signs of revival until Oct'20 there was a sudden collapse in International Travel figures due to rising number of cases and fear of a second wave across European nations. Detection of an emerging and more virulent strain of COVID-19 across London and South England led to tightening of restrictions across Europe ${ }^{30}$.

\footnotetext{
${ }^{30} \mathrm{https}$ ://abcnews.go.com/International/gripped-coronavirus-2nd-wave-europe-faces-grimchristmas/story? $\mathrm{id}=74758388$
} 


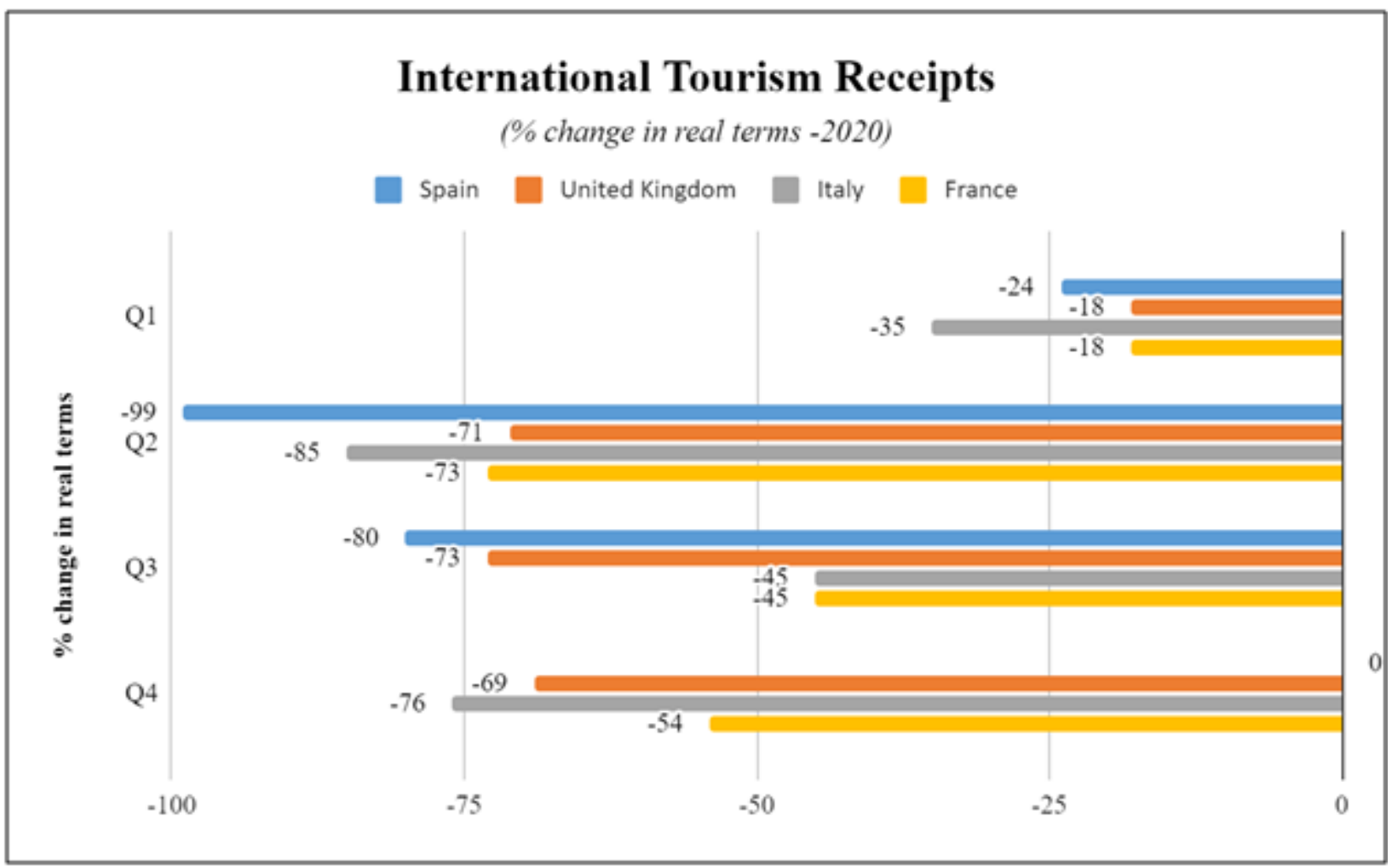

Fig 1.2 Source : Data retrieved from UNWTO barometer for European Union

OECD estimates depicted nearly $80 \%$ shrink in international tourism and losses estimating to USD1.3 trillion $^{31}$ to the global industry. Europe consisted of 15 out of 69 major travel destinations which were shut due to UNWTO Travel Restrictions. Fis 1.2 indicates the Q-o-Q \% change in International Tourism Receipts for UK, Spain, France and Italy. Data retrieved indicates that the industry for all 4 economies took the worst hit during Quarter 2 of 2020 exceeding decline of more than $70 \%$ in Tourism Receipts. Spain witnessed the maximum losses amount to $99 \%$ fall, this can be a high dependency of Spanish Economy on the Tourism Sector i.e. $14.4 \%$ as of 2019. A report by Goldamn Sachs showed that the rebound for Spain in Q4 of 2020 added $1.4 \%$ to Total Spanish Output. While all 4 economies showed a rallying comeback in Q3 , reimposition of lockdown across regions of Europe due to pick up in the Festive season dragged the receipts to lower bound in Q4.

World Travel and Tourism Council (WTTC) ${ }^{32}$ illustrated the loss of 18.8 million jobs across Europe in 2020 within the Travel and Tourism Sector, out of this 11.5 millions jobs were

${ }^{31}$ https://etc-corporate.org/covid-19/

${ }^{32} \mathrm{https} / /$ wttc.org/Research/Economic-Impact/Recovery-Scenarios 
eradicated out European Union region. Fid 1.3 stipulates the growing Employment contribution of Travel and Tourism across all 4 nations in their respective economies from 2014-19. Data ${ }^{33}$ for Spain indicates that tourism contributes $13.5 \%$ to the Total employment followed by $8.8 \%$ in Italy , $8.4 \%$ in The UK and $7.5 \%$ in France. This chart helps us to understand the growing dependence of 4 major european nations on Tourism for employment, which essentially translates into the losses and hits taken by them due to the Virus Outbreak. Statista ${ }^{34}$ estimates show nearly 1.1 million jobs at risk in Italy, $1 \mathrm{mn}$ in the UK , $0.8 \mathrm{mn}$ in Spain and $0.8 \mathrm{mn}$ in France due to the pandemic.

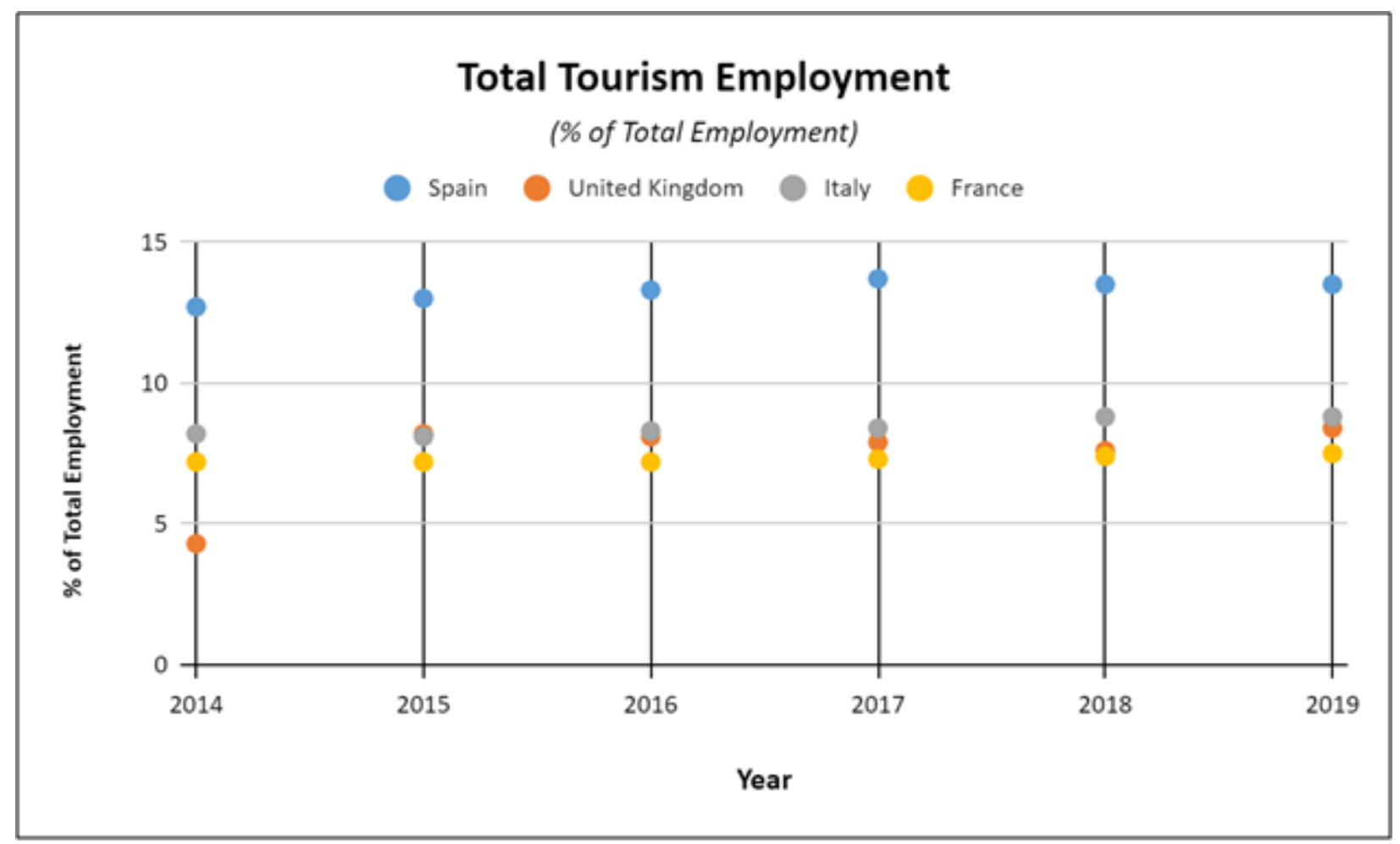

Fig 1.3 Source : Data retrieved from OECD

${ }^{33} 2019$ data for $\%$ contribution

${ }^{34}$ https://www.statista.com/statistics/1107432/travel-and-tourism-jobs-at-risk-europe-coronavirus/ 


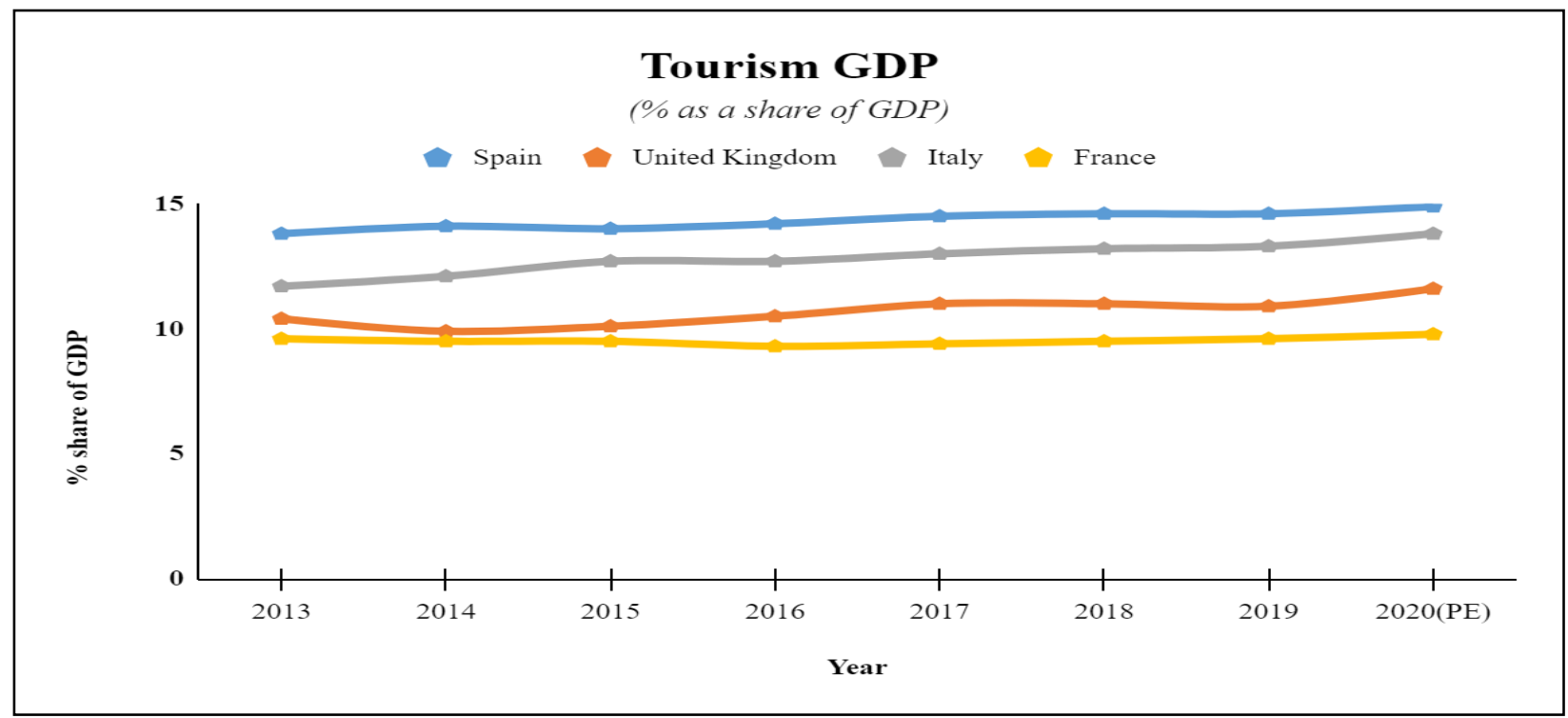

Fig 1.4.3 Source : Data retrieved from OECD

Due to rising popularization of European countries as travel destinations, the Tourism sector for all the economies being evaluated have witnessed a snowballing increase in their contribution to national GDPs. Spain and Italy contributed $14.6 \%$ and $13.3 \%$ to their respective GDPs in 2019. Furthermore, assessing the projected figures for 2020 we can see that economies with highest dependability i.e. Spain and Italy witnessed the steepest decline by EUR 40 billion and EUR 36 billion in their respective annual numbers. In addition to this, The United Kingdom suffered EUR 22 billion in losses with France suffering the most in absolute terms i.e EUR 48 billion $^{35}$.

Amidst rising cancellation and medical reasons with high safety concern, Travel Insurance has turned into an essential indicator of consumer confidence. Fig 1.4.1 indicates the average travel insurance claim amounts in the 4 countries.

\footnotetext{
${ }^{35} \mathrm{https}$ ://www.schengenvisainfo.com/news/174m-travel-tourism-jobs-could-be-lost-in-2020-due-to-covid19-travel-restrictions/
} 
International Journal of Social Science and Economic Research

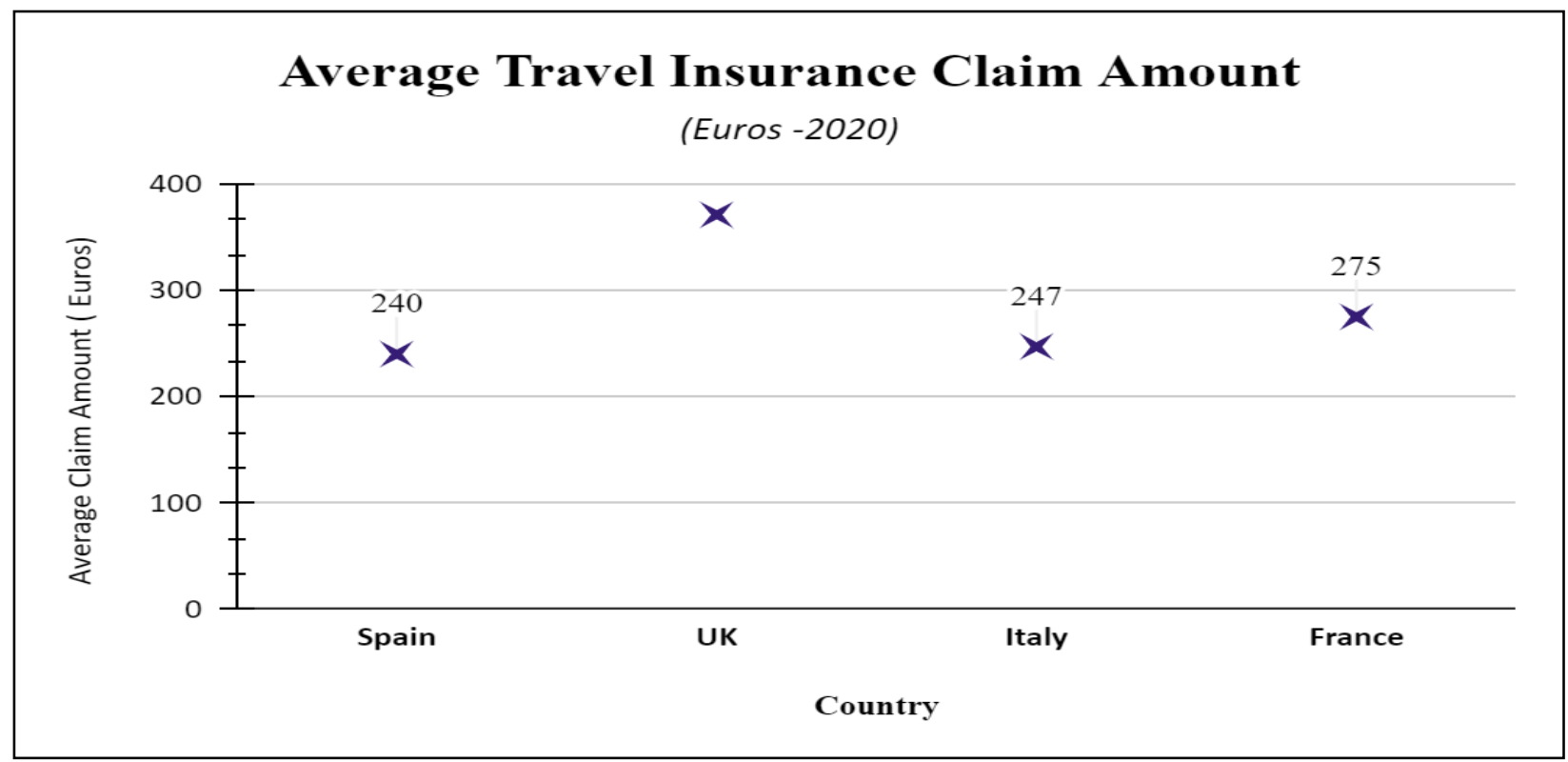

Fig 1.4.2 Source : Alpha Travel

\begin{tabular}{|l|l|l|l|}
\hline & $\begin{array}{l}\text { Average Claim } \\
\text { Amount (Euros) }\end{array}$ & $\begin{array}{l}\text { Travel Insurance } \\
\text { Claims (Cancellations) }\end{array}$ & $\begin{array}{l}\text { Most Common } \\
\text { reason for claim }\end{array}$ \\
\hline Spain & 240 & $17 \%$ & Medical \\
\hline UK & 371 & $11 \%$ & Cancellation \\
\hline Italy & 247 & $4 \%$ & Cancellation \\
\hline France & 275 & $4 \%$ & Medical \\
\hline
\end{tabular}

Source : Alpha Travel

The United Kingdom showed the highest average claim amount of EUR 317 with $11 \%$ claims due to cancellations in travel plans. Followed by France, EUR 275 due to increasing medical concerns. Spain witnessed the maximum claims based on COVID19 cancellations i.e. 17\%. The growing consumer risk averseness is an indicator of higher inclination towards Travel Insurance across European countries. Amidst the rising uncertainty and costs of travellers , 12 popular destinations across Europe have made it necessary to hold travel insurance for visa purposes. 


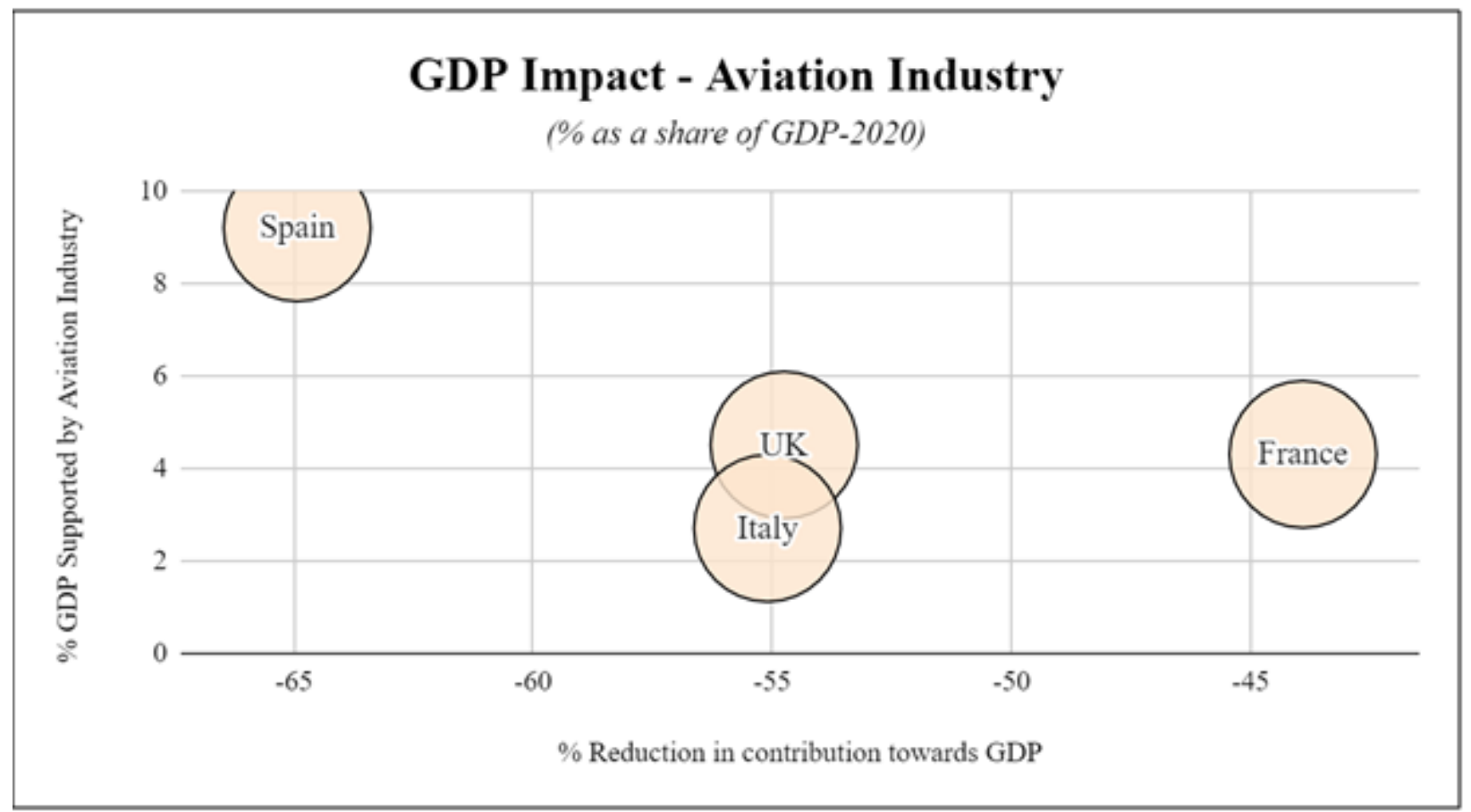

Fig 1.5 Source : Data retrieved from IATA

As per EUROCONTROL ${ }^{36}$, air traffic in Europe was down by 55\% in 2020 compared to 2019 levels. Stakeholders reported EUR 22.2 billion in net losses for European airlines and EUR 33.6 billion revenue losses for airports. With 1.7 billion fewer travelers $51 \%$ of total aircrafts were grounded at the year end across Europe. Fig 1.5 indicates \% GDP supported by the Aviation industry v/s \% reduction in contribution towards GDP.

Spain's aviation industry witnessed a $74 \%$ decline in passenger traffic positing its industry at the most vulnerable point in the chart. Spain operated 1 million fewer flights i.e. $61 \%$ decline from 2019 levels causing 159.7 USD Billion loss in passenger revenues. The UK and Italy suffered $61 \%$ and $60 \%$ fewer flights in 2020. France witnessed a 54\% reduction in Flights thereby contributing to the least reduction out of all nations to its GDP with a passenger revenue loss of USD 108.5 billion.

\begin{tabular}{|c|c|c|c|c|c|c|c|}
\hline Impact & Passenger & & Impact on & Impact & Impact GDP & $\%$ GDP \\
passenger & Impact on & Impact on & $\begin{array}{c}\text { Aviation } \\
\text { GDP } \\
\text { Revenues }\end{array}$ & $\begin{array}{c}\text { Aviation } \\
\text { Aviation }\end{array}$ & $\begin{array}{c}\text { Amployment } \\
\text { empled } \\
\text { supported }\end{array}$ & $\begin{array}{c}\text { Supported } \\
\text { by }\end{array}$ \\
\hline
\end{tabular}

\footnotetext{
${ }^{36} \mathrm{https}$ //www.eurocontrol.int/sites/default/files/2021-01/eurocontrol-think-paper-8-impact-of-covid-19on-european-aviation-in-2020-and-outlook-2021.pdf
} 
International Journal of Social Science and Economic Research

ISSN: 2455-8834

Volume:06, Issue:07 "July 2021"

\begin{tabular}{|c|c|c|c|c|c|c|c|}
\hline & $\begin{array}{c}\text { in } \\
\text { Aviation } \\
\text { (USD } \\
\text { Billions) }\end{array}$ & Industry & employment & $\begin{array}{c}\text { (\% of total } \\
\text { contribution) }\end{array}$ & $\begin{array}{c}\text { by } \\
\text { aviation } \\
\text { (USD } \\
\text { billion) }\end{array}$ & $\begin{array}{c}\text { aviation } \\
\text { (\% of total } \\
\text { contribution) }\end{array}$ & $\begin{array}{c}\text { Aviation } \\
\text { Industry }\end{array}$ \\
\hline UK & -193.6 & $-76 \%$ & 858500 & 53.65625 & -65.7 & 54.75 & $4.50 \%$ \\
\hline $\begin{array}{c}\text { Franc } \\
\text { e }\end{array}$ & -108.5 & $-74 \%$ & 511000 & 46.45454545 & -46.1 & 43.9047619 & $4.30 \%$ \\
\hline $\begin{array}{c}\text { Italy } \\
\text { Spain }\end{array}$ & -117 & $-76 \%$ & 414300 & 58.02521008 & -28.1 & 55.09803922 & $2.70 \%$ \\
\hline Sp & $-74 \%$ & 1116800 & 65.69411765 & -73.5 & 64.92932862 & $9.20 \%$ \\
\hline
\end{tabular}

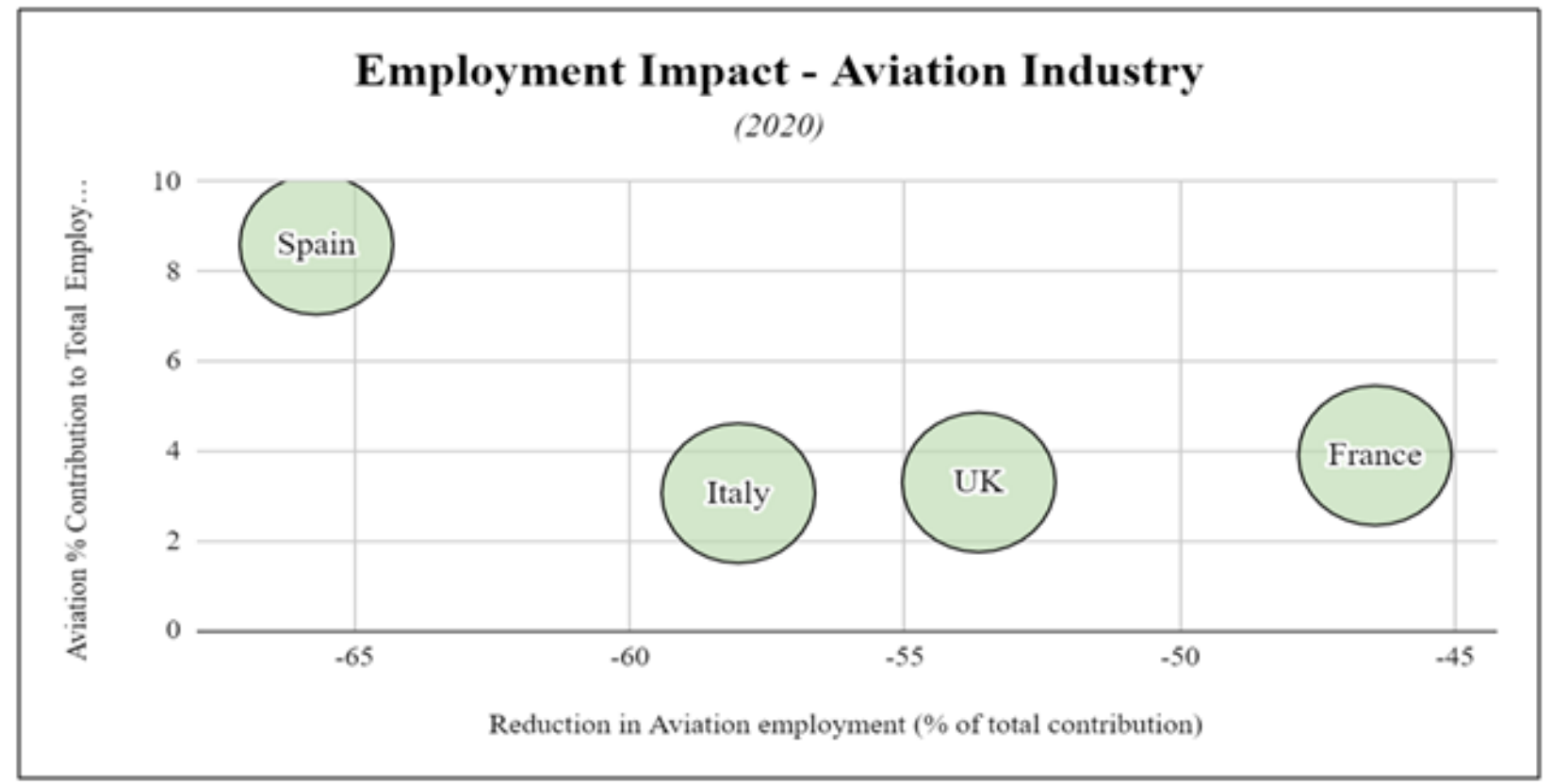

Fig 1.6 Source : Data retrieved from IATA

Significant dependability of Spain transpired to the maximum joint losses i.e. $68 \%$ of total aviation employment i,e. 1116800 job losses in absolute terms. Followed by Italy having 58\% reduction, The UK 53\% and France 47\% reduction in Aviation employment. On average top 10 European airlines witnessed $-45 \%$ to $-67 \%$ decline in flights and $54 \%$ reduction in Intra -Europe flights. The UK- Spain route suffered the maximum by experiencing $70 \%$ decline in their flight and travel level. 
International Journal of Social Science and Economic Research

ISSN: $2455-8834$

Volume:06, Issue:07 "July 2021"

Despite expectations of recovery of European air traffic levels to 51\% of 2019 levels in 2021 , there's an immediate need for reforms to assure scalable capacity levels in the forthcoming years. Aviation industry can draw strong policy implications for maintaining regional connectivity and technological solutions in all aviation domains.

\section{POLICY RESPONSES AND NATIONAL RECOVERY STRATEGIES}

ITALY- On 16th March'20 Italian Council of Ministers introduced measures to aid tourism in order to strengthen and supplement the industry. As part of the response, extraordinary allowances were disbursed to workers employed in Tourism with extension of social security protection ${ }^{37}$ for seasonal workers engaged in the entertainment domain of the industry. The fiscal package comprised of suspension of tax payments ${ }^{38}$, mandatory welfare and social security contributions and necessary insurance premiums for individuals involved in transport services, tourist destination management and other recreational facilities. Taking into account the extent of impairment in the industry, The Ministry of Cultural Heritage and Activities and Tourism announced a 120 million EUR emergency fund to contain COVID-19 contagion.

Due to overwhelming cancellations for travel destinations and hotel accomodation bookings, refunds in the form of vouchers were processed for all travel and tourist packages due to imposition of emergency in the nation. The relief measures also took into consideration the undeclared tourist economy by providing a special compensation of 600 EUR to seasonal workers employed in the sector. For the airline and aviation industry, the Italian government announced 200 million EUR in relief measures to support Air Italy and Alitalia. Despite the severe impact of the virus due to heavy inbound tourism the policy makers aim to relaunch Italy as a hub for safe travel destinations through preparation of extraordinary campaigns to bolster and recover the lost tourist demand.

SPAIN - The United Kingdom, Germany, France which account for $48.28 \%$ of tourist arrivals (International) were one of most affected nations across the globe due to the bolstering rate of COVID-19 Virus transmission. The origin countries contribute $21.6 \%, 13.35 \%$ and $13.33 \%$ of international arrivals respectively. The superior demand for Spain as a travel destination can be attributed to attractiveness and the welcoming capacity of the nation. Spain secured the second position worldwide for its 83.7 million international tourist arrivals in 2019. Pegging the attractiveness of the destination to its Cumulative Tourism Receipts, Spain again stands at the second position with USD 80 billion income. The growing popularity of the Spanish Tourism

\footnotetext{
${ }^{37}$ Social Safety Net and Social protection

${ }^{38}$ Withheld Tax Payments
} 


\section{International Journal of Social Science and Economic Research}

ISSN: $2455-8834$

Volume:06, Issue:07 "July 2021"

sector has led to a noteworthy increase in hotels to 14,840 residences offering $1,82,01,847$ beds and employing over 2,19,796 employees.

Several financial-economic initiatives were undertaken by Spanish government to mitigate the impact of COVID-19 on the tourism sector. These policy measures and initiatives can be classified into three categories, labour/employment and organisational measures and taxation policies.

First , under labour measures a total of 33,86,000 employees affiliated to an organisation filed for temporary employment working in the tourism sector during June, 2020 and more than 2,50,000 self-employed tourism workers received support in the form of financial benefits ${ }^{39}$ during May 2020 by the European commission. Secondly, a total of 6500 million Euros in bank loans with public guarantees were processed to 68,000 organisations out of 80,000 applications by the virtue of Government of Spain. On the regional level, the state provided moratorium on selfemployed and business taxes, deferral on debt to reduce the contagion in the sector.

Whilst the governmental measures ensured the survival of national industry it duly paid attention to the safety of Domestic and Foreign tourist as well, The ICTE ${ }^{40}$ i.e. Institute for Spanish Tourist Quality coordinated National Project of Technical Specifications and Guarantee Seals for the Prevention of COVID-19 for tourist organisations in Spain to ensure the sanitary conditions , reduction of COVID-19 transmission and guidelines for accommodation facilities amongst the travellers thereby minimising the risk.

FRANCE - The fiscal package announced by French Government dedicates 35 billion euros to deferral of tax and social charges of companies. Companies operating in the Travel and Tourism sector were also granted extension for tax deadlines without any additional penalty. In addition to this, distressed companies can request remission of direct taxes imposed on territorial economic contribution and profits. ${ }^{41}$ For individuals the government provided the option to withhold and defer the tax.

"France Relance Plan", a national economic recovery initiative which aims to reduce business taxes by 10 billion euros annually, this includes reduction in property tax on industrial organisations by half (approx. 32000 companies) and compensation to municipal authorities for

${ }^{39} \mathrm{http}: / / w w w . s e p e . e s / H o m e S e p e / C O V I D-19 /$ noticias.html

${ }^{40}$ Guidelines and recommendations

by https://www. mincotur.gob.es/es-es/COVID-19/GuiasSectorTurismo/Hoteles.pdf

${ }^{41}$ Based on individualised examination of requests 


\section{International Journal of Social Science and Economic Research}

ISSN: $2455-8834$

Volume:06, Issue:07 "July 2021"

revenue loss. Travel and Tourism businesses whose business activity was shut down, had suffered loss turnover by 50\% at least (March 2019) and turnover less than 1 million euros were eligible for the "Solidarity Fund of 1 billion euros", grants from 1500 euros to 10,000 euros per month for closure period.

The French Government in May 2020 introduced the Tourism Support Plan ${ }^{42}$ with 18 billion euros being committed to revival and betterment of professionals involved in the industry. The plan was supported by increasing the daily ceiling from 19 euros to 38 euros for restaurants and establishment of sectoral health guidelines to assist the industry. Lastly, the government constituted a Tourism Sector Committee to monitor and alleviate the repercussions of COVID-19 crisis and succor the cash flow operations in the wake of cancellations.

UNITED KINGDOM - The industry generates 130 billion pounds annually in the form of economic activity and 39 billion pounds in taxation for the British Government ${ }^{43}$. Although the UNWTO anticipated a 20-30\% drop in International Tourism and $80 \%$ sustainability risk for small and medium firms the actual loss to this sector of the economy was much greater.

In it's 2020 budget the UK Government assured the substantiality of the sector through various policy measures directed towards the Travel and Tourism industry. All businesses linked to hospitality, leisure and travel were given business rate exemptions for 2020-21 financial year with an additional 25,000 GDP grant businesses with small scale operations with rateable property value of more than GBP 15000 and less than GBP 51000. Under CBILS i.e. Coronavirus Business Interruption Loan Schemes 1.2 million GBP in government backed bank loans was disbursed to small and medium sized businesses. Tourist businesses operating on rental basis were ensured of no eviction policy by the government, directions regarding the same were issues to commercial property landlords. ${ }^{44}$ Example, Travelodge- an affordable tourist accommodation provider across the UK requested a rent waiver of GBP 146 million across two years from its landlords. This initiative by the government bolsters the financial security of business through relaxation on rental obligations. Cash grant up to $80 \%$ of normal profits for self employed business/individuals. ${ }^{45}$ Implementation of Job Retention Scheme to cover $80 \%$ of wages upto GBP $2500^{46}$

\footnotetext{
${ }^{42}$ https://wttc.org/Portals/0/Documents/Reports/2021/WTTC\%20COVID19\%20Strong\%20Policies\%201802.pdf?ver=2021-02-27-131406-913

${ }^{43}$ UK Hospitality Workforce Commission, 2018

${ }^{44}$ No eviction due to non payment of rent for 3 months

${ }^{45}$ https://wttc.org/COVID-19/Government-Policies
} 
For international tourists, the Department of Health UK confirmed spaces across Heathrow airports and hotel facilities were dedicated towards quarantine for passengers, these facilities were also prepared to accommodate the medical staff, key medical personnel and first respondents. Amidst the economic uncertainty looming over Travel and Tourism the Government of UK borne the expenses for all these facilities.

\begin{tabular}{|c|c|c|c|c|}
\hline \multicolumn{5}{|c|}{ Summary - Government policy for Tourism 2020-21 ( Top European Travel } \\
Destinations)
\end{tabular}

${ }^{46}$ For employees on Furlough 


\begin{tabular}{|c|c|c|c|c|}
\hline \multirow{3}{*}{ Tourist } & $\begin{array}{c}\text { Rent Waiver } \\
\text { request and No } \\
\text { eviction Policy }\end{array}$ & & $\begin{array}{c}\text { Tax deadline } \\
\text { extensions }\end{array}$ \\
\hline & $\begin{array}{c}\text { Free government } \\
\text { provided } \\
\text { Quarantine } \\
\text { Facility }\end{array}$ & $\begin{array}{c}\text { Project of Technical } \\
\text { Specifications and } \\
\text { Guarantee Seals }\end{array}$ & $\begin{array}{c}\text { Extraordinary } \\
\text { campaigns to } \\
\text { promote Italian } \\
\text { Tourism }\end{array}$ & $\begin{array}{c}\text { Tourism Sector } \\
\text { Committee to } \\
\text { ensure tourist } \\
\text { safety }\end{array}$ \\
\hline
\end{tabular}

\section{2: Changing Traveler's Perception}

The outbreak of Novel Coronavirus has altered every aspect of the travel and hospitality industry. Series of weekly reports have indicated the swelling importance of economic vulnerability and personal safety in travelers' decision making process (Deloitte, 2021). With a surge in vaccination drives more than $80 \%$ of adults ${ }^{47}$ are willing to travel for vacation purposes, whilst numerous studies have depicted the consumer behaviour towards high cleanliness standards, privacy and less crowded places, this paper roots into the traveller's perception for destination preference, risk aversion levels and factors affecting the choice of destinations.

The initial half of the survey aims to understand the Impact of COVID-19 on travel plans and bookings of the respondents. 94.4\% of the participants responded with "Yes" implying that their travel plans were significantly affected due to the unprecedented virus outbreak ( Fig 2.1).

${ }^{47} 2000$ people survey AusTRALIA, Canada , India , Japan Mexico and UK 
International Journal of Social Science and Economic Research

ISSN: $2455-8834$

Volume:06, Issue:07 "July 2021"

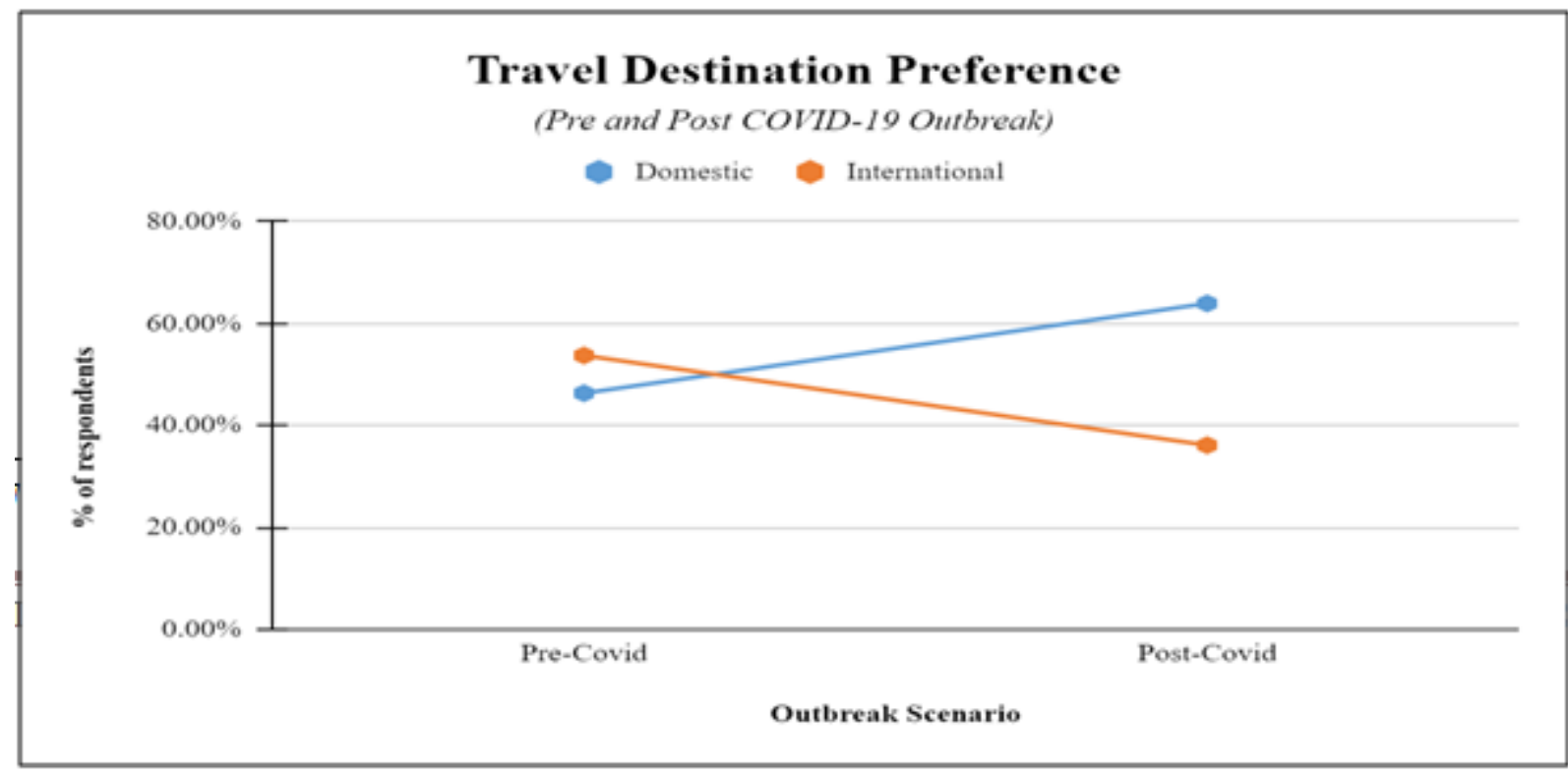

\begin{tabular}{|c|l|l|l|}
\hline \multirow{3}{*}{$\begin{array}{c}\text { Travel Destination } \\
\text { Preference }\end{array}$} & Pomestic & $46.30 \%$ & $63.90 \%$ \\
\cline { 2 - 4 } & International & $53.70 \%$ & $36.10 \%$ \\
\cline { 3 - 4 } & & & \\
\hline
\end{tabular}

To explore the Travel Destination Preference respondents were enquired with the choice of Domestic and International travel options. The results exemplified that prior to COVID-19 outbreak $53.70 \%$ of respondents preferred to travel Internationally for leisure compared to $46.3 \%$ preferring to travel domestically. (Fig 2.2.) exhibits the stark movement in destination choice.

Whereas, post the crisis $63.9 \%$ of the participants opted to travel domestically, this shift can be attributed to International Travel restrictions and ambiguity ${ }^{48}$. These results were in accordance with India's largest conglomerates dealing in Travel and Tourism, SOTC Travel's Thomas Cook ${ }^{49}$, a recently report indicated that current domestic levels are 30\% higher than the Pre-COVID levels ${ }^{50}$ due to limiting options and availability of International Travel.

${ }^{48} 36.1 \%$ preferring International Travel

${ }^{49} \mathrm{https}$ ///timesofindia.indiatimes.com/business/india-business/domestic-travel-business-30-higher-thanpre-covid-levels-sotcs-vishal-suri/articleshow/81567161.cms

502019 for Q1 (January-March period) 
International Journal of Social Science and Economic Research

ISSN: 2455-8834

Volume:06, Issue:07 "July 2021"

\begin{tabular}{|c|l|c|c|c|}
\hline \multirow{4}{*}{$\begin{array}{c}\text { Travel Insurance } \\
\text { Preference }\end{array}$} & & \multicolumn{4}{|c|}{ Travel Destination Preference } \\
\cline { 2 - 5 } & Yes & 26 & 42 & 68 \\
\cline { 2 - 5 } & No & 13 & 27 & 40 \\
\cline { 2 - 5 } & Total & 39 & 69 & 108 \\
\hline
\end{tabular}

Similar trend was observed in preference for Travel Insurance, whilst only $25 \%$ of travellers prefer buying Insurance prior to the pandemic, post the crisis $75 \%$ of them were inclined to purchase travel insurance. A rapid transition in dynamics has been observed due to ambivalence pertaining to risk and individual accountability.

\begin{tabular}{|c|c|c|c|}
\hline \multirow{2}{*}{$\begin{array}{c}\text { Travel Insurance } \\
\text { Preference }\end{array}$} & Yes & Pre-Covid & Post-Covid \\
\cline { 2 - 4 } & no & $75 \%$ & $67 \%$ \\
\cline { 2 - 4 } & & & $37 \%$ \\
\hline
\end{tabular}

Amidst the looming unpredictability nearly 34 countries have made Travel Insurance Coverage necessary for Visa authorizations and permits. In lieu of increasing prediction for Domestic travel , companies have repositioned their domestic packages with essential medical benefits and $100 \%$ travel cancellation coverage plans as well ${ }^{51}$. Another notable aspect of the survey was that $66.6 \%$ of International travellers preferred buying Travel Insurance over $60.86 \%$ of domestic travellers which indicates the risk averseness linked to outbound tourism.

\footnotetext{
${ }^{51} \mathrm{https}$ ://www.outlookindia.com/outlookmoney/insurance/consider-travel-insurance-before-packing-yourbags- 6562
} 
SquareMouth, leading travel US insurance platform, has witnessed a spike in monthly sales figures primarily in the Trip Cancellation Coverage domain thereby ensuring 100\% reimbursement incase of cancellation due to aforementioned /covered reasons ${ }^{52}$

\begin{tabular}{|c|c|c|c|c|}
\hline \multirow{6}{*}{$\begin{array}{c}\text { Factors affecting } \\
\text { the choice of } \\
\text { Destination }\end{array}$} & \multicolumn{4}{|c|}{ Travel Destination Preference } \\
\hline & & International & Domestic & Total \\
\hline & $\begin{array}{l}\text { Quarantine } \\
\text { Regulations }\end{array}$ & 28 & 53 & 81 \\
\hline & $\begin{array}{l}\text { Number of } \\
\text { Covid Cases }\end{array}$ & 27 & 52 & 79 \\
\hline & $\begin{array}{l}\text { Possibility of } \\
\text { Lockdown } \\
\text { restrictions }\end{array}$ & 23 & 50 & 73 \\
\hline & $\begin{array}{c}\text { Availability } \\
\text { of Healthcare } \\
\text { Assistance }\end{array}$ & 19 & 23 & 42 \\
\hline
\end{tabular}

In the second half of the survey participants stated the factors affecting their travel plans as per the choice of travel destination. The results indicated that the majority of the travellers were concerned about the Quarantine Regulations imposed by the National Governments, since the majority of countries ensure strict adherence to quarantine rules and period for inbound tourists due to virus threat. Example ${ }^{53}$, UK government announced strict 11 day quarantine period in Government managed facilities from 33 "red list countries",

\footnotetext{
52 https://www.wbrc.com/2021/04/02/going-vacation-experts-say-consider-travel-insurance/

${ }^{53}$ https://www.jdsupra.com/legalnews/uk-imposes-strict-quarantine-9232255/
} 


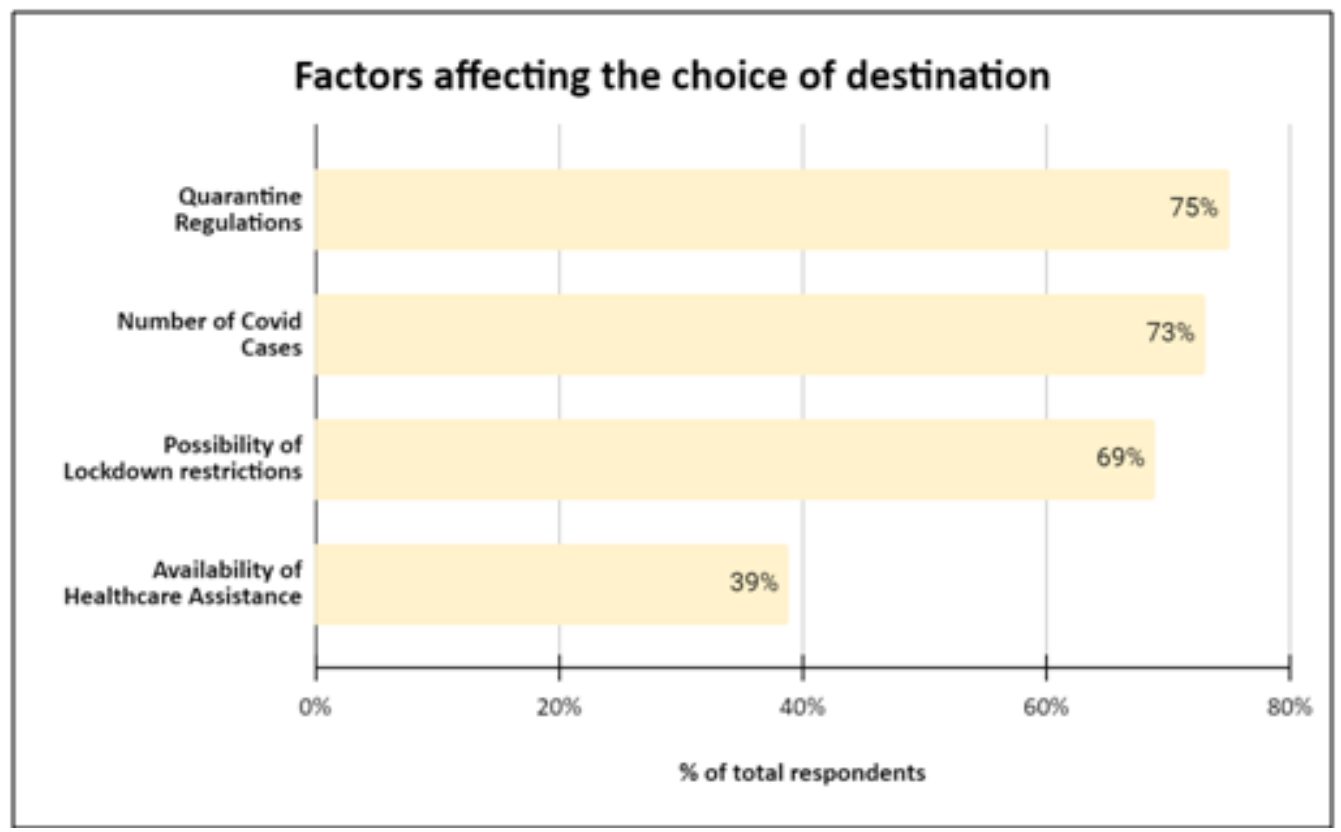

On contrary, numerous national governments have relaxed their quarantine regulations to promote the revival of the industry, example, Thailand government curtailed quarantine regulations from 2 weeks to 10 days starting 1st April 2021 whilst stating that the country might consider quarantine enforcement from 1 st October 2021 entirely ${ }^{54}$ since shorter quarantine destinations are likely to attract more foreign travellers. Country's COVID journey i.e. Number of Cases till date also played a significant role in driving traveller's preference since larger figures are an indicator of increased exposure to viruses thereby making the travel destination less popular.

Although National Lockdowns have been considered an effective strategy for curbing the virus spread in some of the developed economies , 69\% of respondents in our survey stated the noteworthy influence of this factor. National lockdowns have proven to be deceptive for international migrants in countries such as US , India and European nations ${ }^{55}$. Lastly , only $49 \%$ of respondents agreed to placing healthcare assistance a critical factor to choice of destination making it the least popular one. Although pre crisis level suggested strong inclination of

\footnotetext{
${ }^{54} \mathrm{https}$ ://www.hindustantimes.com/lifestyle/travel/thailand-to-reduce-quarantine-for-visitors-to-revivetourism-101616135777544.html

${ }^{55}$ https://www.ft.com/content/de721f35-d228-48de-bd9f-d2168b16aba6
} 
travellers towards countries with superior healthcare system for international passengers, post crisis experiences have repositioned the focus on their own residents and citizens ${ }^{56}$.

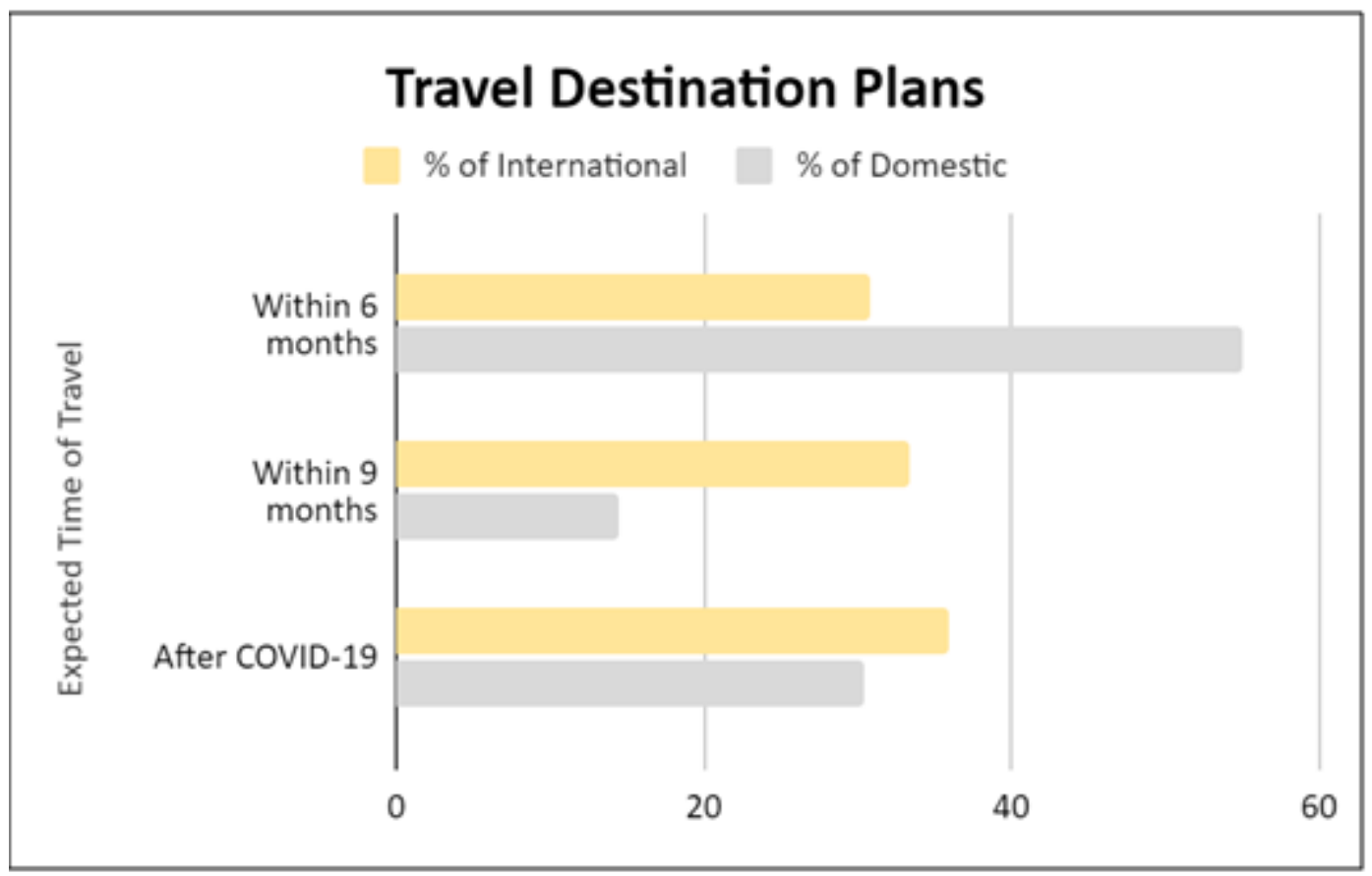

Travel destination plans when expressed as a function of expected period of travel indicated that a greater part of the travelers i,e. 55.07\% picked Domestic Tourism within 6 months from March 2021 , on the contrary participants willing to travel internationally for leisure ( $35.89 \%)$ preferred travelling after the eradication and suppression of COVID-19. The results are in accordance with the prevailing trend of greater popularisation of Domestic tourist destinations in the short run as mentioned above, the response patterns instills strong implications for Policy Makers of Nations where economic activity was predominated by the Travel and Tourism sector.

\section{POLICY IMPLICATIONS}

In order to mitigate the negative effects of the COVID-19 pandemic on the travel and tourism industry it is essential to take action to help various stakeholders of this sector deal with the crisis, most importantly, the labour, the industry/business and tourists/consumers.

\section{A. Labour and Employment}

\footnotetext{
${ }^{56} \mathrm{https}$ ://www.outlookindia.com/outlooktraveller/travelnews/story/71125/international-travellers-wont-beprioritised-for-covid-19-jabs
} 


\section{International Journal of Social Science and Economic Research}

ISSN: $2455-8834$

Volume:06, Issue:07 "July 2021"

- Job retention can be promoted by providing incentives to companies which are retaining their employees, along with other benefits like relief from fiscal payments. Moreover vulnerable labour groups should be protected by extending and expanding on the unemployment benefits and even accompany them during the economic hardship faced during the COVID-19 pandemic.

- Since the tourism sector is a labour intensive sector, countries should extend a hand of support to those who have been a victim of unemployment due to the pandemic. This should be done by promotion of learning and developing new skills which would aid during the recovery phase. Skills that may serve advantageous and useful include: how to make a new product, digital skills, marketing and even market intelligence. This can be done by providing free online courses in partnership with their local universities and educational institutions for the people who have experienced a job loss and even for seasonal workers.

- Promotion of employment in this sector can be done through the promotion of fairs aimed at providing employment in the tourism industry, along with developing online government platforms where tourism jobs and openings are regularly posted. Those companies which provide employment opportunities can be given incentives like a special credit line, loans and even tax benefits.

- Invest in government funded vocational and educational training specifically targeted towards the tourism sector employment, particularly for those employees who lost their means of livelihood due to the inception of the pandemic. Some international organizations offer free courses like UNWTO Online Academy, which the governments can promote, for the tourism personnel to gain knowledge in marketing, available in different languages.

\section{B. Tourism Industry and Businesses}

- It is important to support the company's liquidity by allocating funding lines specific to the travel and tourism industry. This can be a part of the Emergency Funds and Programme of the Country. These funding lines can be open to those countries that are most affected by the pandemic, which can help them avoid bankruptcy and even resume the operations shortly after normalcy kicks in. This will contribute to the recovery of the travel and tourism sector and help to return the supply to the market.

- Extend investment mechanisms in order to support the Micro, Small and Medium-sized enterprises (MSMEs), especially in the short-term, which will be essential for their 


\section{International Journal of Social Science and Economic Research}

ISSN: $2455-8834$

Volume:06, Issue:07 "July 2021"

survival. This support can be in the form of fast and subsidized loans and even assistance with their working capital. They can also facilitate temporary reliefs on important bills like rent and electricity. Moreover, providing managerial support to these businesses will be a step forward in facilitating their recovery in the tourism sector.

- It is important to take a look at the taxes and regulations that impact the travel and aviation sector. For example liberalization of air transport should be promoted, this will help in extending air capacity facilitating recovery. Moreover, temporary restrictions on corporate taxes, taxes on air travel, tourism taxes and even VAT which is charged on restaurants and hotels/accommodations. All these measures facilitate the path of recovery for this sector.

- The countries should also bolster marketing, in order to attract international tourism fairs and events. This is really important for European countries as they are heavily dependent on their tourism sector. Reduction in fees for participating in travel shows and fairs for companies can provide significant support to these businesses.

\section{Tourists or Consumers}

- Government partnership with the private sector in the tourism sector can help consumers get fair treatment in the market. For example, exempting customers from cancelling charges of accommodations and air travel, allow rescheduling at no extra cost and even settle any disputes arising with customers in a peaceful matter instead of taking it to the court. This would help in boosting demand in the travel and tourism sector.

- Visitors should be provided with the latest information regarding travel restrictions with easy accessibility. Countries should lift up restrictions in a timely and organized manner and as and when it is safe to do so, and in sync with other nearby travel destinations. If the level of public health threat is less than restrictions should be lifted and tourism and travel should be encouraged. The aim should be to make travel as convenient as possible for the travellers. Visa on arrival can also prove to be a significant boost in the demand for air travel and tourism in that particular destination.

- It's very important to first stimulate the domestic tourism demand, since domestic tourists are actually going to be the first ones to travel. Marketing activities aimed at reviving domestic demand should be facilitated by providing special prices through promotional activities for destinations that heavily depend on tourism. This should be done by taking complete advantage of social media and digital marketing tools, which have proved to be essential in today's times of social distancing. 
International Journal of Social Science and Economic Research

ISSN: $2455-8834$

Volume:06, Issue:07 "July 2021"

\section{CONCLUSION}

In conclusion ,_COVID-19 has provoked serious economic implications for the travel and tourism industry. Amidst surging global uncertainty, sustainability has become the primary concern for travel destinations such as Euurope. It is vital that national governments ensure business continuity through crucial policy implementation and rescue packages. The future recovery of all businesses intertwined with travel and tourism is densely reliant on travellers behavioural pattern. In sum, this paper encourages national government and tourism councils across the globe to take into account the dynamic perception of travellers whilst encouraging vocational and educational training in this sector. The effectiveness of any policy pertaining to tourism industry is measured by employment security, long-term sustainability of enterprises and dynamism of travel culture during times of ambiguity.

\section{REFERNCES}

1. Alan A. Lew (2011) Tourism's Role in the Global Economy, Tourism Geographies: An International Journal of Tourism Space, Place and Environment, 13:1, 148-151, DOI: $10.1080 / 14616688.2010 .531046$

2. Bas, T., \& Sivaprasad, S. (2020). The Impact of the COVID-19 Pandemic Crisis on the Travel and Tourism Sector: UK Evidence. SSRN Electronic Journal. doi:10.2139/ssrn.3623404

3. Bloom DE, Canning D (2006) Epidemics and Economics. Program on the Global Demography of Aging Working Paper No. 9, Harvard Initiative for Global Health. $\begin{array}{lllll}\text { Retrieved } & 1 & \text { August } & 2008 & \text { from }\end{array}$ http://www.hsph.harvard.edu/pgda/Working\%20Papers/2006/BLOOM_CANNINGWP9. 2006.pdf.

4. Choi, S. (2021, January 12). How Covid-19 Related Consumer Behavior is Changing the Travel Industry": Publicis Sapient. Retrieved from https://www.publicissapient.com/insights/covid19_perspectives_on_the_coronavirus/how -covid-19-is-reshaping-consumer-behavior-and-what-that-means-for-travel-brands-right$\underline{\text { now }}$

5. Christoff. (2021). New Global Survey Predicts Massive Summer Rebound for Travel. Retrieved from https://www.travelpulse.com/news/features/new-global-survey-predictsmassive-summer-rebound-for-travel.html 
International Journal of Social Science and Economic Research

ISSN: 2455-8834

Volume:06, Issue:07 "July 2021"

6. CNN. (2020, October 13). Coronavirus Outbreak Timeline Fast Facts. Retrieved from https://edition.cnn.com/2020/02/06/health/wuhan-coronavirus-timeline-fastfacts/index.html

7. ETC. (2021). 2020 marks the worst year for international arrivals to Europe in over 30 years. Retrieved from https://etc-corporate.org/news/2020-marks-the-worst-year-forinternational-arrivals-to-europe-in-over-30-years/\#_ftn1

8. Farzanegan, M. R., Gholipour, H. F., Feizi, M., Nunkoo, R., \& Andargoli, A. E. (2020). International Tourism and Outbreak of Coronavirus (COVID-19): A Cross-Country Analysis. Journal of Travel Research, 1-6.

9. Gössling, Scott \& Hall (2020): Pandemics, tourism and global change: a rapid assessment of COVID-19, Journal of Sustainable Tourism. Retrieved from https://doi.org/10.1080/09669582.2020.1758708

10. Haque, T. H., \& Haque, M. O. (2018). The swine flu and its impacts on tourism in Brunei. Journal of Hospitality and Tourism Management, 36, 92-101. doi:10.1016/j.jhtm.2016.12.003

11. Hung, K. K., Mark, C. K., Yeung, M. P., Chan, E. Y., \& Graham, C. A. (2018). The role of the hotel industry in the response to emerging epidemics: A case study of SARS in 2003 and H1N1 swine flu in 2009 in Hong Kong. Globalization and Health, 14(1). doi:10.1186/s12992-018-0438-6

12. Iacus, S. M., Natale, F., Santamaria,, C., Spyratos, S., \& Vespe, M. (2020). Estimating and projecting air passenger traffic during the COVID-19 coronavirus outbreak and its socio-economic impact. Safety Science.

13. IATA. (2020). What can we learn from past pandemic episodes? Impact of past Outbreaks on Aviation. Retrieved from https://www.iata.org/en/iatarepository/publications/economic-reports/what-can-we-learn-from-past-pandemicepisodes/.

14. Joo, H., Maskery, B. A., Rotz, L. D., Berro, A. D., Lee, Y. -K., \& Clive , B. M. (2019). Economic Impact of the 2015 MERS Outbreak on the Republic of Korea's TourismRelated Industries. Health Security, 17(2). 


\section{International Journal of Social Science and Economic Research}

ISSN: $2455-8834$

Volume:06, Issue:07 "July 2021"

15. Kaushal, V., \& Sidharth, S. (2020). Hospitality and Tourism Industry amid COVID-19 Pandemic: Perspectives on Challenges and Learnings from India. International Journal of Hospitality Management.

16. Kreiner, N. C., \& Ram, Y. (2020, October 19). National tourism strategies during the Covid-19 pandemic. Retrieved from https://www.ncbi.nlm.nih.gov/pmc/articles/PMC7572067/

17. Kuo, H., Chen, C., Tseng, W., Ju, L., \& Huang, B. (2008). Assessing impacts of SARS and Avian Flu on international tourism demand to Asia. Tourism Management, 29(5), 917-928. doi:10.1016/j.tourman.2007.10.006

18. Kuo, Hsiao-I \& Chang, Chia-Lin \& Chen, Chi-Chung \& Huang, Biing-Wen \& McAleer, Michael. (2009). Estimating the Impact of Avian Flu on International Tourism Demand Using Panel Data. Tourism Economics. 15. 10.2139/ssrn.1365228.

19. Liew, V. K. (2020). The effect of novel coronavirus pandemic on tourism share prices. Journal of Tourism Futures, Ahead-of-print(Ahead-of-print). doi:10.1108/jtf-03-20200045

20. Maphanga, Petrus \& Henama, Unathi. (2019). The Tourism Impact of Ebola in Africa: Lessons on Crisis Management. African Journal of Hospitality, Tourism and Leisure. 8. $1-13$.

21. Monterrubio, J.C. (2010) 'Short-term economic impacts of influenza A (H1N1) and government reaction on the Mexican tourism industry: an analysis of the media', Int. J. Tourism Policy, Vol. 3, No. 1, pp.1-15.

22. Montevago, J. (2021). Almost $80 \%$ of Consumers Want to Travel in 2021. Retrieved from https://www.travelmarketreport.com/articles/Almost-80-of-Consumers-Want-toTravel-in-2021

23. Nepal (2020): Travel and tourism after COVID-19 - business as usual or opportunity to reset?, Tourism Geographies. https://doi.org/10.1080/14616688.2020.1760926

24. OECD (2021), "Key tourism indicators", OECD Tourism Statistics (database), https://doi.org/10.1787/e5d0c450-en 
International Journal of Social Science and Economic Research

ISSN: 2455-8834

Volume:06, Issue:07 "July 2021"

25. OECD. (2021). Tourism Policy Responses to the coronavirus (COVID-19). Retrieved from https://www.oecd.org/coronavirus/policy-responses/tourism-policy-responses-tothe-coronavirus-covid-19-6466aa20/

26. Page, S., Song, H., \& Wu, D. C. (2011). Assessing the Impacts of the Global Economic Crisis and Swine Flu on Inbound Tourism Demand in the United Kingdom. Journal of Travel Research, 51(2), 142-153. doi:10.1177/0047287511400754

27. Rosselló, J., Santana-Gallego, M., \& Awan, W. (2017). Infectious disease risk and international tourism demand. Health Policy and Planning. doi: 10.1093/heapol/czw177

28. Schengen Visa. (2020, November 02). 174m Travel \& Tourism Jobs Could Be Lost in 2020 Due to COVID-19 Travel Restrictions. Retrieved from https://www.schengenvisainfo.com/news/174m-travel-tourism-jobs-could-be-lost-in2020-due-to-covid-19-travel-restrictions/

29. The Hindu. (2020, October 15). How the Covid-19 pandemic has hit GDP growth. Retrieved from https://www.hindustantimes.com/india-news/how-the-covid-19pandemic-has-hit-gdp-growth/story-7enJJQpWNdPMb2UGAHdomO.html

30. Uğur, N. G., \& Akbiyık, A. (2020). Impacts of COVID-19 on the global tourism industry: A cross-regional comparison. Tourism Management Perspectives.

31. UNWTO. (2021). WORLD TOURISM ORGANIZATION. Retrieved from https://www.unwto.org/unwto-world-tourism-barometer-data

32. Williams, C. C. (2020). Impacts of the coronavirus pandemic on Europes tourism industry: Addressing tourism enterprises and workers in the undeclared economy. International Journal of Tourism Research. doi:10.1002/jtr.2395

33. World Travel and Tourism Council. (2021). WTTC COVID-19 Strong Policies.

34. WTTC. (2020). Economic Impact Reports. Retrieved from https://wttc.org/Research/Economic-Impact

\section{APPENDIX}


International Journal of Social Science and Economic Research

ISSN: 2455-8834

Volume:06, Issue:07 "July 2021"

Table 1

\begin{tabular}{|c|r|r|r|r|}
\hline $\begin{array}{c}\text { Total Tourism Employment as \% of Total } \\
\text { Employment }\end{array}$ & Spain & $\begin{array}{c}\text { United } \\
\text { Kingdom }\end{array}$ & Italy & France \\
\hline 2014 & 12.7 & 4.3 & 8.2 & 7.2 \\
\hline 2015 & 13 & 8.2 & 8.1 & 7.2 \\
\hline 2016 & 13.3 & 8.1 & 8.3 & 7.2 \\
\hline 2017 & 13.7 & 7.9 & 8.4 & 7.3 \\
\hline 2018 & 13.5 & 7.6 & 8.8 & 7.4 \\
\hline 2019 & 13.5 & 8.4 & 8.8 & 7.5 \\
\hline
\end{tabular}

Table 2

\begin{tabular}{|c|c|c|c|c|c|c|c|}
\hline $\begin{array}{c}\text { passenger } \\
\text { Revenues } \\
\text { in } \\
\text { Aviation } \\
\text { (USD } \\
\text { Billions) }\end{array}$ & $\begin{array}{c}\text { Impact } \\
\text { Impact on } \\
\text { Aviation } \\
\text { Industry }\end{array}$ & $\begin{array}{c}\text { Impact on } \\
\text { Aviation } \\
\text { employment }\end{array}$ & $\begin{array}{c}\text { Impact on } \\
\text { Aviation } \\
\text { employment } \\
\text { (\% of total } \\
\text { contribution) }\end{array}$ & $\begin{array}{c}\text { Impact } \\
\text { GDP } \\
\text { supported } \\
\text { by } \\
\text { aviation } \\
\text { (USD } \\
\text { billion) }\end{array}$ & $\begin{array}{c}\text { Impact GDP } \\
\text { supported } \\
\text { by } \\
\text { aviation } \\
\text { (\% of total } \\
\text { contribution) }\end{array}$ & $\begin{array}{c}\text { Supported } \\
\text { by } \\
\text { bvP } \\
\text { Aviation } \\
\text { Industry }\end{array}$ \\
\hline UK & -193.6 & $-76 \%$ & 858500 & 53.65625 & -65.7 & 54.75 & $4.50 \%$ \\
\hline $\begin{array}{c}\text { Franc } \\
\text { e }\end{array}$ & -108.5 & $-74 \%$ & 511000 & 46.45454545 & -46.1 & 43.9047619 & $4.30 \%$ \\
\hline Italy & -117 & $-76 \%$ & 414300 & 58.02521008 & -28.1 & 55.09803922 & $2.70 \%$ \\
\hline Spain & -159.7 & $-74 \%$ & 1116800 & 65.69411765 & -73.5 & 64.92932862 & $9.20 \%$ \\
\hline
\end{tabular}

Table 3

\begin{tabular}{|c|c|c|c|}
\hline $\begin{array}{c}\text { Average Claim Amount } \\
\text { (Euros) }\end{array}$ & $\begin{array}{c}\text { Travel Insurance Claims } \\
\text { (Cancellations) }\end{array}$ & $\begin{array}{c}\text { Most Common reason for } \\
\text { claim }\end{array}$ \\
\hline
\end{tabular}




\begin{tabular}{|c|c|c|c|}
\hline Spain & 240 & $17 \%$ & Medical \\
\hline UK & 371 & $11 \%$ & Cancellation \\
\hline Italy & 247 & $4 \%$ & Cancellation \\
\hline France & 275 & $4 \%$ & Medical \\
\hline
\end{tabular}

Table 4

\begin{tabular}{|c|c|c|c|c|}
\hline & $\begin{array}{c}\text { Tourism as \% of } \\
\text { GDP }\end{array}$ & $\begin{array}{c}\text { Tourism as \% in } \\
\text { total exports }\end{array}$ & $\begin{array}{c}\text { Enterprises in } \\
\text { T\&T }\end{array}$ & $\begin{array}{c}\text { Total Employees in tourism } \\
\text { industry (2019) }\end{array}$ \\
\hline Spain & 14.6 & 16 & 237786 & 2605000 \\
\hline UK & 10.9 & 8 & 307942 & 3300000 \\
\hline Italy & 13.3 & 8 & 218327 & 3508200 \\
\hline France & 9.6 & 6 & 695377 & 2010000 \\
\hline
\end{tabular}

Table 5

\begin{tabular}{|c|c|c|c|c|c|c|c|}
\hline $\begin{array}{c}\text { passenger } \\
\text { Revenues } \\
\text { in } \\
\text { Aviation } \\
\text { (USD } \\
\text { Billions) }\end{array}$ & $\begin{array}{c}\text { Impact } \\
\text { Impact on } \\
\text { Aviation } \\
\text { Industry }\end{array}$ & $\begin{array}{c}\text { Impact on } \\
\text { Aviation } \\
\text { employment }\end{array}$ & $\begin{array}{c}\text { Impact on } \\
\text { Aviation } \\
\text { employment } \\
\text { (\% of total } \\
\text { contribution) }\end{array}$ & $\begin{array}{c}\text { Impact } \\
\text { GDP } \\
\text { supported } \\
\text { by } \\
\text { aviation } \\
\text { (USD } \\
\text { billion) }\end{array}$ & $\begin{array}{c}\text { Impact GDP } \\
\text { supported } \\
\text { by } \\
\text { aviation } \\
\text { (\% of total } \\
\text { contribution) }\end{array}$ & $\begin{array}{c}\text { Supported } \\
\text { by GDP } \\
\text { bviation } \\
\text { Industry }\end{array}$ \\
\hline UK & -193.6 & $-76 \%$ & 858500 & 53.65625 & -65.7 & 54.75 & $4.50 \%$ \\
\hline $\begin{array}{c}\text { Franc } \\
\text { e }\end{array}$ & -108.5 & $-74 \%$ & 511000 & 46.45454545 & -46.1 & 43.9047619 & $4.30 \%$ \\
\hline Italy & -117 & $-76 \%$ & 414300 & 58.02521008 & -28.1 & 55.09803922 & $2.70 \%$ \\
\hline Spain & -159.7 & $-74 \%$ & 1116800 & 65.69411765 & -73.5 & 64.92932862 & $9.20 \%$ \\
\hline
\end{tabular}


International Journal of Social Science and Economic Research

ISSN: 2455-8834

Volume:06, Issue:07 "July 2021"

Table 6

\begin{tabular}{|c|c|c|}
\hline & $\begin{array}{c}\text { Impact GDP } \\
\text { supported by } \\
\text { aviation } \\
\text { (\% of total } \\
\text { contribution) }\end{array}$ & $\begin{array}{c}\text { \% GDP Supported by Aviation } \\
\text { Industry }\end{array}$ \\
\hline UK & -54.75 & 4.5 \\
\hline France & -43.9047619 & 4.3 \\
\hline Italy & -55.09803922 & 2.7 \\
\hline Spain & -64.92932862 & 9.2 \\
\hline
\end{tabular}

Table 7

\begin{tabular}{|c|c|c|c|c|}
\hline & $\begin{array}{c}\text { Impact on Aviation } \\
\text { employment (\% of total } \\
\text { contribution) }\end{array}$ & \multicolumn{3}{|c|}{$\begin{array}{c}\text { Aviation Contribution to } \\
\text { Employment }\end{array}$} \\
\hline UK & -53.65625 & \multicolumn{3}{|c|}{3.3} \\
\hline France & -46.45454545 & \multicolumn{3}{|c|}{3.898359145} \\
\hline Italy & -58.02521008 & \multicolumn{3}{|c|}{3.056506849} \\
\hline Spain & -65.69411765 & \multicolumn{3}{|c|}{8.594539939} \\
\hline \multirow{6}{*}{$\begin{array}{l}\text { Factors affecting the } \\
\text { choice of Destination }\end{array}$} & \multicolumn{4}{|c|}{ Travel Destination Preference } \\
\hline & & International & Domestic & Total \\
\hline & Quarantine Regulations & 28 & 53 & 81 \\
\hline & Number of Covid Cases & 27 & 52 & 79 \\
\hline & $\begin{array}{c}\text { Possibility of Lockdown } \\
\text { restrictions }\end{array}$ & 23 & 50 & 73 \\
\hline & $\begin{array}{c}\text { Availability of Healthcare } \\
\text { Assistance }\end{array}$ & 19 & 23 & 42 \\
\hline
\end{tabular}


International Journal of Social Science and Economic Research

ISSN: 2455-8834

Volume:06, Issue:07 "July 2021"

Table 8

\begin{tabular}{|c|c|c|c|c|}
\hline \multirow{3}{*}{$\begin{array}{c}\text { Travel Insurance } \\
\text { Preference }\end{array}$} & \multicolumn{4}{|c|}{ Travel Destination Preference } \\
\cline { 2 - 5 } & Yes & 26 & 42 & 68 \\
\cline { 2 - 5 } & No & 13 & 27 & 40 \\
\cline { 2 - 5 } & Total & 39 & 69 & 108 \\
\hline
\end{tabular}

Table 9

\begin{tabular}{|c|c|c|c|}
\hline \multirow{4}{*}{$\begin{array}{c}\text { Travel Destination } \\
\text { Preference }\end{array}$} & Domestic & $\begin{array}{c}\text { Pre- } \\
\text { Covid }\end{array}$ & $\begin{array}{c}\text { Post- } \\
\text { Covid }\end{array}$ \\
\cline { 2 - 4 } & International & $53.70 \%$ & $63.90 \%$ \\
\hline & & & \\
\hline
\end{tabular}

Table 10

\begin{tabular}{|c|c|c|c|}
\hline \multirow{4}{*}{ Travel Insurance Preference } & & Pre-Covid & Post-Covid \\
\cline { 2 - 4 } & Yes & $25 \%$ & $67 \%$ \\
\cline { 2 - 4 } & \multirow{2}{*}{ no } & $75 \%$ & $37 \%$ \\
\hline
\end{tabular}

